\title{
INTERNATIONAL FinANCIAL CRISES
}

\author{
RUDI DORNBUSCH $\dagger$ \\ STANLEY FISCHER
}

\section{CESifo Working PAPER No. 926 \\ Category 6: Monetary Policy and InTERnational FinanCe \\ MARCH 2003}

An electronic version of the paper may be downloaded

- from the SSRN website: www.SSRN.com

- from the CESifo website: www.CESifo.de 


\title{
INTERNATIONAL FINANCIAL CRISES
}

\section{Foreword}

Our friend and colleague Rüdiger Dornbusch passed away before he was able to complete his book based on the Munich Lectures in Economics that he gave in November 17, 1998, at the Center for Economic Studies of Ludwig-Maximilians-Universität. The lectures contain a fascinating overview of the mechanics and history of international financial crises showing the breadth and ingenuity of this eminent scholar. The lectures were lively and provocative, full of important insights and observations. Interestingly enough, Dornbusch expressed a substantial mistrust in the actions of political decision makers, supervisory agencies and central banks in the game that leads to the crisis and even collapse of financial systems, and he advocated supranational supervisory actions as a remedy.

CES has decided to prepare a transcript of the lectures, which are also available in the Internet as full length-videos. I am grateful to Paul Kremmel for his assistance.

Munich, March 2003

\author{
Hans-Werner Sinn \\ Ifo Institute \\ Poschingerstrasse 5 \\ 81679 Munich \\ Germany \\ sinn@ifo.de
}

JEL Classification: F3, E5, F2 
These remarks were prepared to introduce Rudiger Dornbusch's Munich Lectures in Economics, at the Center for Economic Studies, Ludwig-Maximilians University, Munich, on November 17, 1998.

\title{
LAUDATIO: RUDIGER DORNBUSCH
}

\author{
Stanley Fischer
}

It is an honor for me to introduce this year's Distinguished CES Fellow who is to deliver the Munich Lectures in Economics, Professor Rudiger Dornbusch; it is an enormous pleasure for me to introduce to you a superb economist, an outstanding speaker, a remarkable person, my co-author, and my friend for nearly thirty years, Rudi Dornbusch.

I would like to tell you about four aspects of Rudi: the young scholar; the policy economist and polemicist; the teacher; and the human being.

The young scholar

I first met Rudi Dornbusch at the University of Chicago in the autumn of 1969. I was a freshly minted Ph.D. from MIT, and he was one of an outstanding group of graduate students, among them Jacob Frenkel and Michael Mussa. They were students of Harry Johnson and Robert Mundell, in Milton Friedman's Chicago. Some, among them especially Rudi and Jacob Frenkel, honored the great Lloyd Metzler, who was still at Chicago.

It must have been a wonderful place and time to be a graduate student in international macroeconomics, not only because of the world-famous faculty, even more because of the synergy among outstanding students.

Somehow I found myself on Rudi's thesis committee, a very junior third to Mundell and Johnson. At the time I valued mathematical virtuosity more than I should have. But I looked at Rudi's thesis, "A Monetary Theory of Currency Depreciation" again last week, and realized how excellent it is, displaying a mind so clear and expositional talents so formidable that it can have been written only by a young master. It is also obviously the work of a student of Robert Mundell's -- and Rudi was most of all a Mundell student. I know that because I was there. But if you should doubt it, look at the beautiful series of papers Mundell produced from the late 1950s to the mid 1960s, reprinted in his 1965 classic book, Monetary Theory, and see how similar is the elegance and clarity of style, exposition, and thought in the classic papers Rudi wrote in the $1970 \mathrm{~s}$.

That was the young Rudi Dornbusch: the scholar who left Chicago for Rochester, where he spent two years, before returning to Chicago to teach at the Business School; the teacher whose notes for his business school students later provided the basis of the aggregate demand and supply apparatus in the Dornbusch-Fischer textbook; the scholar who wrote a series of path-breaking papers, several of which later appeared in his classic book, Open-Economy Macroeconomics. 
I left Chicago to return to MIT at the same time as Rudi returned to join the Chicago Business School faculty in 1973. But when in 1975, MIT needed an international macroeconomist, it did not take very much to persuade my senior colleagues that he was the person we wanted. So Rudi came to MIT. It was MIT's good fortune; it was certainly my good fortune; and it was also Rudi's, for he needed to move on to another intellectual environment - albeit, an environment that at the beginning, he did not like. But within a short time of arriving he had written his classic overshooting article, he was soon recognized as an outstanding classroom teacher and thesis adviser, and he soon became central to the MIT Department of Economics.

And for the next decade, he continued to produce outstanding theoretical articles, at the same time as his interest in policy issues grew. Some of the best articles of that period are collected in Exchange Rates and Inflation (1988). One of my favorites in that book is his paper on the problem of disinflation, "Inflation Stabilization and Capital Mobility", a paper whose relevance to the problems confronting countries trying to stabilize from high inflation using an exchange rate anchor has grown over the years.

The policy economist

In the introduction to Exchange Rates and Inflation, written in 1988, Rudi explained:

Over time my interests, and some beliefs, have changed very much. As a student, and early in my career, models and results were exciting, and there could not be enough of it. Today my interest is mostly in policy and policy-oriented research. The difference is subtle: in modeling, the main interest is in the structure and the implications; in policy-oriented research, by contrast, the central issue is to capture a problem, even if one does not write down the whole maximization problem. That is a weakness of the policy approach, and it might even be enough to reject it altogether. I do not think so. On the contrary, there is a broad complementarity between modeling and identifying and 'painting' issues.

I am not sure this characterization of the difference between modeling and policy work is entirely right, for the problem in both cases is to capture the essence of a complicated situation in a tractable and relevant form. But no doubt there is more latitude for pursuing the logically more interesting and empirically less relevant angles in modeling than in policy analysis.

Rudi is one of the outstanding policy economists of our time. He has worked on a range of applied problems, typically the major international and national economic issues of the day, but also -- as in his exceptionally interesting work on hyperinflation -- on the most interesting parts of economic history. But even when he is working on economic history, he is thinking about policy issues, for instance in applying the lessons of the dissolution of the Austro-Hungarian Empire to the breakup of the Soviet bloc. Among his policy papers, the most famous may well be the Brookings paper predicting the Mexican peso crisis, but that is only one of many papers on the economic problems of Latin American countries. Another that repays rereading is his 1990 paper with Sebastian Edwards, "Macroeconomic Populism", which accurately depicts a temptation to which policymakers in Latin America and other countries used often to succumb, and no doubt sometimes will succumb in future. 
Although Rudi describes himself as having shifted to working on policy issues by 1988 , the change was gradual, and analytic articles -- albeit on more clearly policy-related issues than before -- continued to appear in the 1980 s and into the $1990 \mathrm{~s}$.

In his more popular articles, in his columns, and sometimes on the podium -- where his wit and the speed of his mind make him an exciting and formidable presence, Rudi is one of the finest polemicists in the profession. He seems to take as his leitmotif a statement of Keynes "Words ought to be a little wild for they are the assault of thoughts on the unthinking" - and no one could accuse him of not erring on the wild side.

You may wonder how anyone can write as much as Rudi does. The technique is simple -it is to stop agonizing and start writing. Rudi will make three or four bullet points on the page, typically in the midst of a mess of doodles, and then start writing. His first drafts are just that, drafts to be improved. The technique works.

The teacher

Rudi is a spectacularly successful teacher, in the classroom, in supervising theses, and through his textbooks. In the classroom the secret of his success is careful preparation: in earlier years, the well-developed lecture notes that he handed out, more recently, the shorter notes summarizing the models and facts that are to be the subject of the lecture. As his interests have shifted to policy, he has also shifted to teaching in the Sloan School. Business School students are known to be excessively demanding, but by all accounts Rudi's courses in the Sloan School are regularly sold out.

As a thesis adviser, Rudi has had few peers. Every outstanding international macroeconomist who has been to MIT -- and many of them have -- including Jeff Frankel, Paul Krugman, Maury Obstfeld and Ken Rogoff is a Rudi student, and so are most of the best macroeconomists who were at MIT. There are outstanding Rudi students all over the globe: the Italians, among them Mario Drahi, Francesco Giavazzi, and Alberto Giovanni; Pedro Aspe in Mexico; and Andre Lara Resende in Brazil; and many more. While they all acknowledge their debts to Rudi, it is not necessarily the best economists who have benefitted most from working with him, for they would have been outstanding anyway. Rather it is the legion of students, many of them from abroad, who have been part of Rudi's schule, the group that meets weekly at 8 a.m. to discuss their theses, who reflect what his intellectual generosity has meant for generations of MIT students. He has students who are devoted to him all over Latin America, and in much of the rest of the world. In the richly deserved devotion of this legion of students to their teacher and friend lies the greatest compliment to his teaching and mentoring.

I have had the good fortune to collaborate with Rudi in the writing of two textbooks. One of them Macroeconomics, has given me as much satisfaction as anything else $I$ have done in my scholarly life. The book has sold well over a million copies worldwide, and we can justly feel that we have contributed to educating the readers, many of them in developing countries. Few things are as pleasant as to encounter a student who says that he or she used our book, and even better, that they remember something in it. We have both had that experience all over the world, from Sweden and Russia in the North, all the way to Tasmania, Chile and South Africa in the South -- and I thank Rudi for 
having made that possible. However not all encounters with students are totally encouraging: in one country I saw a group of students with copies of Dornbusch and Fischer in hand, standing shyly at the back of a group of officials, with whom I was talking, so walked over to chat with them. One of them said, "Professor, thank you, this is such an excellent book. But please sir, could you recommend an easier one?"

Rudi

Finally, let me salute the exceptional person who you will hear tonight. Rudi is among the most talented of men, and among the warmest, the most generous, with his time and himself, available for his students and his friends whenever they need him. My life is far richer for having had the good fortune to meet Rudi, and to have him as a friend.

That is why it is such a pleasure for me to be able to introduce to you, Rudi Dornbusch. 


\section{DAY ONE}

It's a great privilege to be here. It's wonderful to be introduced by Stan Fischer who was generous enough to interrupt saving the world to be here. When I saw him to my own surprise today here, I knew there was a crisis. It had to be the Sinn Krise. Let me assure you that the IMF has enough money to solve any problem that local authorities cannot deal with.

This is not the first time that I'm at Munich University. Forty years ago, when my brother was a student here I was here once early in the morning. I'm afraid the reason was that it was raining outside, and the Hofbrauhaus wasn't open yet. It's a great privilege to be back under more distinguished circumstances, and I'm very much honoured by the privilege of being the CES Fellow of this year, the invitation to be here, and the very, very distinguished audience that has come.

I have decided to talk about international financial crises. I decided a year ago with a great confidence that they would still be there and that the answers would remain to be found. Let me give you a preliminary report of what is going on. Of course, listening to an economist is a problem for anyone, but remember that economists are people who are good with numbers but lack the charisma to be accountants. My discussion will centre on the difference between old style financial crises that we had perhaps up to the ' 80 s and the new kind that we see today. And that is a distinction between the slow motion crises of the past, where things were going in the wrong direction and in the end would not end well, but slow motion sufficiently so that mid-course correction could avoid the crisis, and even if the crisis happened, it was a very strictly local event and mostly interesting for the governing finance minister, but not a dramatic setback, even for the country, less for the region, and surely for the world.

By contrast, the new kind of crisis is dramatic, it happens in fast motion, it's far away from local, it's ascribed to the world financial system, and it ends not only with the finance minister going overboard, but much of the country too. And I think it's important to ask where is that difference, and how do we have to rethink the international financial system and national economic management to recognise those new factors.

The new factors surely are not the speculators. The picture of a world economy where five hedge funds in New York have lunch to decide whom they will attack next, only then to overthrow a poor and unsuspecting country that has saved hard for decades, worked hard for decades, but is suddenly declared the victim, surely can't be the right view. Perhaps the story is well told, why it isn't the right view, of a poor Christian who was thrown to the lions and the man was very, very afraid of what was to come and he stared at the big lion and he fell on his knees to pray to the lord and he said, "Lord, please make this happen fast and without much pain." And as he looks at the lion, he notes the lion is also on his knees. And he says, "Mister Lion, Sir. I am praying because this is very, very bad. But why, Mister Lion, Sir, are you praying?" And the lion said, "I'm not praying, I'm saying grace." That is surely not what international financial crises are about. 
We have to dig a little bit deeper and we have to remember it wasn't just George Soros, it was the Vatican, and probably Muenchner Rueck also. Where would we look for the difference? The side issues of excess capacity in the world economy, low commodity prices - all of that is not going to give us a world financial crisis. Where should we look? The answer surely is that capital movements today are the central issues. Capital movements badly used are an extraordinary risk factor, and that the rest are interesting and complicating factors.

The view of the old crises is that they happened without much capital mobility. That perhaps there was some World Bank money. Perhaps they were some bank loans. But that was mostly a side issue. There was a government that had some reserves and some World Bank funds to supplement and it had some bad policies: budget deficits, overvalued currency leading to current account deficits which in turn led to a steady loss of reserves, and anything that is steadily being depleted, in the end, is going to be gone, and everybody could foresee that in half a year or a year, the reserves on the current course of events would be gone, and when the reserves were gone, then policy would have to change.

Of course that movement of transition would be very painful and because the pain was so acute, one would try and avoid it, and the way to avoid it would be to put tariffs and quotas and to restrict imports and to try and subsidise exports and to pursue a whole range of bad policies only to push off the day of reckoning, but without much success. And in the end there was a day of reckoning, which would lead to a 15 per cent devaluation, which would lead the minister of finance to fall from office, and then life would start all over again, at the beginning with great joy, because the devaluation had produced a gain in competitiveness which allowed an expansion of the economy, and then in the second chapter, one would do the same thing again. And those were very predictable things, and they were deeply uninteresting to the international financial system and they surely wouldn't have warranted an article on the front page of the Financial Times.

Nothing could be more different from what is happening now where suddenly in the afternoon of an otherwise sunny day, the world financial system wants 50 billion dollars from a country, and the country doesn't have the $\mathbf{5 0}$ billion dollars, and the IMF cannot get there fast enough, and the next thing, the place blows up, and there is a massive depreciation of the currency, pervasive bankruptcy, and the fire spreads to the next country. And one after the other, until all of Asia is gone, and then Russia, and then Brazil and who knows what comes next. Dramatically different in all its characteristics, and dramatically different in the implications for the world economy and for everybody anywhere.

Crises are now different in that they involve very large amounts of very short-term money. That is one aspect. Second, that the economy is highly leveraged around that money, so that when something happens, the whole house of cards collapses. And thirdly, the world economy is deeply global, through the financial structures and that means that when something happens anywhere, it happens everywhere. So that of course makes international financial crises today something really interesting.

There is a second question of a distinction, whether emerging market crises are very, very different than those that happen in rich countries. The '92 events of Europe, are they deeply different from what happened in Asia? In some respects, they aren't deeply 
different. When Italy comes under attack, everybody can figure out that England is next. And when Italy goes, everybody knows that England is gone. And if you look at Scandinavia, much of the same problems that you see in emerging markets are clearly present. There is a difference of degree, that in emerging markets, the extent of mismanagement in every aspect of finance and politics, it's very, very pervasive, and therefore, the blow-up is bigger. Whereas in Britain, the exchange rate crisis is in some way a sideshow because the rest is pretty clean. And the same could be said even of Italy. So I believe there it's a difference of degree, and it is interesting to ask where is it, but it isn't a totally different kind of crisis to the one that Scandinavia, Britain and Italy suffered in 1992, with its aspects of contagion, with its aspect unsustainable exchange rate regimes, and what we've seen in Asia and are still witnessing in Russia, or Latin America.

So let me focus on these new financial crises and ask where do they come from? And I want to ask where do these crises come from in a deep way. And the answer is going to be a vulnerability of balance sheets, and then I want to ask what are the post-mortems of the crises? What are interesting little details of how those countries sank and the emphasis there is on the profound mismanagement of the monetary authorities. And then I want to ask what are the unresolved questions of research around these crises, and those are the timing. It's very easy to predict a crisis, but then you have to wait for two years until it happens. There is the issue of contamination. Why innocent bystanders get hit. And there is the last issue of the depth of crisis. Why are they so traumatic, leaving a crater that is unbelievably deep? Where should we look for that explanation?

Then lastly, I want to ask, with that autopsy of financial crises, where should we look for reform? Should we go the direction of saying this is a shootout world, and if the speculators have big guns, then we should equip the IMF with bigger guns? Or whether we should look for systemic differences that are far more focusing on precaution and pre-emption rather than the weapons that get used in conflict and finally, at the level of countries, what is a good way to get out, and what is a bad way? So that is my menu for what lies ahead in the next few minutes.

Let me take my central argument about the new financial crises. Think of a world characterised by a banker's image. The banker's image is that it's not speed that kills; it's the sudden stop. And that of course was seen in all of these countries, where money was happily coming at an ever-rising pace, and then suddenly it wasn't coming. And when it wasn't coming, that was the end of the story.

Why is it the end of the story? The argument is that the national balance sheet is extremely vulnerable. You could live for years and years and years with a balance sheet like that, and nothing ever happens, and nobody ever talks about you, and you are a great story of success, with high growth and a miracle. And then something happens and then it turns out that that very vulnerability is such that it's a dramatic end of all success.

Think of drunk driving. Think of someone who has made a great expertise of drunk driving, regularly drives drunk, tells you that he never has a problem, and one day there is a terrible, terrible accident. And he'll say, "Well, it was the red light. It wasn't my being drunk. Normally that light is green." And that is, of course, the story of Asia. Drunk driving, which for years has worked, with a financial structure that is recklessly, 
recklessly unsound. But the light was green and then one day it wasn't green, and then the house of cards came crumbling down.

Where specifically is the problem? The problem is you could call value at risk, to use the modern term, the technical term for looking at balance sheets, and ask, in a bad scenario, what could the losses be? Value at risk comes, one, from the maturity issue. That the balance sheets in emerging market economies have extraordinarily short-term liabilities. And that means people can want to get their money back tomorrow afternoon, and when someone wants their money back, they all want their money back. And if they all want their money back, there is no way for an economy to pay at short notice. And if I can't repay, then they'll be much more eager to get their money, and as the bank run occurs, of course the rest of the economy will collapse with it. Maturity is the first issue. And this, of course, means to structure your maturities, to have relatively little that is short term and therefore a reasonable chance to meet to those liabilities, should they be called.

The second issue is denomination. There is a very big risk for a country to denominate its liabilities in foreign exchange. Something that they cannot print, something that they cannot get their hands on, and therefore something that is very vulnerable if in fact the exchange moves, the burden of those liabilities increases and bankruptcy of the country and the underlying companies becomes a big issue. Because if that is seen to be happening, then of course, everybody wants their money before it happens, and as they try to get it, they provoke the very collapse that I'm describing.

The third issue is balance sheets that have highly volatile substances in them. Highly volatile substances like foreign exchange liabilities, or stocks; their market value can change rapidly, and as it does, it produces insolvency. And the third issue is national credit risk. That a balance sheet is sensitive if not one company of one bank in a country comes under suspicion, but if suddenly all of them come. Then of course, for the country, we have not the rating of the best and not the rating of the second best, but suddenly everybody goes under and as a result the entire country loses access to credit, loses access to an ability to meet its short term commitments, and with that, it falls into bankruptcy. And bankruptcy that rarely happens without a collapse in asset prices on the inside, and the exchange rate on the outside.

I've described the vulnerability of the balance sheet as the central issue in looking for the explanation of the bigtime crises. But that is not enough because we have to go behind the national balance sheet and ask: What could the government do in order to defend a precarious situation? And here, of course, comes the underlying fragility. The underlying fragility in a corporate structure or in a banking structure, which is such that the traditional means to defend a currency and the external front of a country with that, is to raise interest rates.

But if you have a fragile corporate or banking or social structure that is intolerant of a loss of growth, then interest rates cannot be raised. Interest rates cannot be raised if the banks are weak, because then all their loans turn bad. The banking system goes bellyup. If the corporate structure has too much leverage, think of Korea, debt-equity ratios of 5 to 1,10 to 1 , and more. Higher interest rates mean that companies go bankrupt overnight. And a social structure that is vulnerable if you lose growth, then the politics goes kaput, and when the politics goes kaput, the investors of course, will leave very rapidly. 
Throughout Asia, we had that underlying fragility in the domestic economy that was such that interest rates could not be raised to defend the exchange rate. But if interest rate cannot be raised to defend exchange rates, then the slightest piece of bad news means capital outflows, those capital outflows quickly become punitive. If there isn't a lot of reserves in the central bank, then everybody knows this is going to end with a currency crisis, and that currency crisis is sure because the government isn't making it expensive for the speculators to bet against the currency, they can't afford to, so it's only a question of time. Anything that is only a question of time is certain to happen, and anytime that rumour spreads, of course, all the sharks will come: the big ones, and all the little ones along.

So I believe we have to look one to the fragile balance sheet, the national balance sheet, and second, the inability to raise interest rates to defend the currency as the combination of facts that explains to us why it is that we get these currency crises.

To look for specific examples, think of Thailand. In Thailand the banking system had invested in a real estate bubble that was totally glorious. It is not the first and the last country to do so. But the real estate bubble had matured. It was about to go. Higher interest rates were the one thing that the real estate bubble could not afford and therefore the banks could not afford.

In Thailand, every bank owns a politician; every politician owns two banks. And so you have a wonderful harmony that the interest rate mustn't go up. But if the interest rate cannot go up, then all the little things that make Thailand suddenly a little bit less attractive come into play and then it becomes attractive to speculate against the country and because the interest rate isn't high, that doesn't cost a lot, and anything that doesn't cost a lot and promises a lot becomes a world-wide investor sport. And that's what happened in Thailand. The story is the same: they couldn't raise interest rates because financing companies would have had big delinquencies on all the people who had bought their motorcycles. If you look at the companies that couldn't afford high interest rates because they had taken on huge debt burdens, and therefore even a small change in interest rates meant a very dramatic change in their cash flow and therefore a risk of bankruptcy. The country was taken hostage to the inability to defend their currency because the financial structure was too fragile.

And we see exactly the same in every one of the Asian situations. You can't raise the interest rate, because the financial structure is too fragile. Much the same was there in the ' 92 crisis. In Britain high interest rates just wasn't very popular. And at 15 per cent, to do an extra per cent just to show the speculators how serious you were was a little too much, and you gave up. In Sweden there was a glorious day when the central bank raised interest rates above 100 per cent. And everybody understood that that would not last three. And it didn't last three days. So, inability to defend their currencies, because the interest rate produces financial distress in the banking system, in companies, or in politics is a central part of the story. And the more fragile the external side with short maturities, and the more fragile the domestic side with sensitivity to a period of high interest rates, the more likely that a currency crisis succeeds.

Look at the little details in Thailand. The Thai government, in an attempt to bail out all their friends on the home front, lowered interest rates below Singapore. And that meant to any investor that borrowing from Thailand and investing in Singapore was a really 
good idea. That would mean being subsidised to do just that. And to be ordinary economist, that's what they did. But as the government experienced the capital outflows, and the pressure on the exchange rate, the central bank used its reserves to offer forward contracts. And that, of course, meant that you could risk-free invest in Singapore and be paid to do that. Which everybody proceeded to do with the central bank taking the counterpart on something like $\mathbf{3 0}$ billion dollars of forward contracts. And that continued until they had lost all their money. So they actually were subsiding the speculators to do their own brewing.

In the process an important lack of transparency on what the reserves actually were and that, in fact, they had all disappeared made the sudden news that they weren't there any more far more brutal, caused the exchange rate collapse to be more intense, forced everybody to rush much more rapidly to try and cover their positions, and in the process, drive the exchange rate even further. So I would pay a lot of attention to bad policy, not only in allowing a bad financial system that is intolerant of a period of high interest rates, but also of the defence of the exchange rate with very in-transparent policies batting away even the last penny of reserves, only then to be left with a big crisis afterwards.

What I have described about Thailand is very much the same in Korea. In Korea, a government that has mismanaged the details of economic policy for the past 20 years with great success has protected the country against any kind of foreign capital inflows. Why? Because they wanted to protect the domestic monopolies. In an attack of insanity, they thought it was really good that their own that their own merchant banks should be allowed to borrow in Tokyo and invest in Russian and Brazilian bonds. And that's where the Korean problem was made.

Having invested in them, they soon found out three percent in Tokyo and 18 per cent on Russian bonds isn't only what you get: that adversity can hit and suddenly what you hold goes down and you're illiquid and people want their money back and you have a Korean national crisis which cannot be addressed because the interest rates cannot be raised because the entire industrial structure is fantastically leveraged with debt. Wherever you look the story is the same: a fragile financial system intolerant of high interest rates, an extremely liquid external liabilities structure, and then you're only waiting for an accident. I think there is nothing deeper in it, and the central part is the mismanagement of finance nationally, and not the speculative attack, which is just taking advantage of money that is lying on the pavement and that's what god invented speculators for.

Let me come to the issues raised in the post-mortem. And the first is timing: Why is it so hard to predict a currency crisis ahead of time? I think that is not surprising after you decide that the deep answer is the vulnerability of the structure. If the financial structure is vulnerable, then yes, it could happen anytime, and it also might happen never. Everybody has predicted for the last 30 years that the Middle East will blow, and one day it will but it hasn't happened yet.

And the same is true of financial structure. Anyone who has looked at the Korean financial structure would have said if there's ever a problem, it's going to be a gigantic problem. Or at Indonesia, or at Thailand. Anybody who had looked at Hong Kong would have said, it's going to be very hard to get a crisis here. Even if there is a heavy storm. If you looked at Argentina, you would say, pretty nice financial institutions. Very 
hard to see how they go bankrupt. So I believe that the sheer fragility does not mean that the accident must happen. It just means the potential is there. For that reason it is very difficult to announce that within a short period of time, there will be a crisis.

But the Thai crisis was clearly predicted because it was underway for a year. And it was only a question of time because it was so well understood that the government couldn't raise the interest rate and without it, it couldn't hold the exchange rate, and if the exchange rate went then the whole house of cards would go.

But the timing in some instances is easier to pin down, surely once some pressure has come. We know what structures cannot bear the interest rates that are needed to defend it. Look at Brazil for example. Real interest rates of 30 per cent are not viable. Neither in the credit system nor in economic growth, and without economic growth, Brazil is not viable. And the same would be true of course of all of Scandinavia in the '92 episode. So once it gets going, then we can really tell who is going to last long, and for that reason will not have a lot of adverse speculation, because simply, they can make it expensive to the speculators. And those who cannot last long and therefore will be the focus of attention. Because while it is true that the speculators lose for the moment, they understand that in the end the big prize will come.

It is hazardous. You can predict that a Mexico will go down, but it will take two years before it happens. The theorem is that financial crises take much, much longer to come than you think and then they happen much faster than you would have thought. So you have a chance to be wrong twice. But any time a financial crisis has to do not just with a balance sheet issue, but also with a loss of growth and a seriously misaligned currency, then prediction becomes much easier because then you move into a situation that really cannot last for any length of time even with relatively good weather, then it is a question of a year. And that was surely the Mexican situation and that is surely the Brazilian situation unless now with the IMF package, an extraordinary outbreak of confidence changes the path of events.

Let me come to the second issues of contamination. And here of course is a very, very important system issue: the question whether one country's accident, whether deserved or not, then spreading to other countries is something that must and should be avoided at all costs. That there ought to be a firewall, and the system should do all and everything to avoid that the next one, and the next one gets drawn in. Surely that is the argument for the domestic monetary authorities to rescue too-large-to-fail banks to avoid the spread to the whole system and we have seen that argument substantially in Asia. That an innocent Indonesia was the victim of a tyrant which itself may or may not have been the victim of circumstances.

But we will have to say why is it that Indonesia and Taiwan did not? And the answer, of course, is that in Indonesia you have fantastic short-term liabilities, with a dramatic domestic mismanagement of investment. And in Taiwan, by contrast, you have shortterm liabilities that are extremely small relative to the country's reserves. And they could pay them all off and have $3 / 4$ of their reserves left. And that mean no accident ever happened. The country kept happily going on, in a region that had trouble with some impact on their growth, but nothing like a crisis. So the distinction between a Taiwan that didn't have a crisis and everybody else that did, surely lies exactly in that number, how large are the short term liabilities relative to the country's reserves - with Taiwan the good case, and Indonesia, for example, the bad one. 
But it also has to do with the underlying banking structure. If you look at Hong Kong, you ask: "Why are they still there?" Because their banks are very, very sound. And if you ask why is Indonesia burned? Because their banks were very unsound before everything started, and of course, by now even more so. So I believe the contamination issue is not that you sit next door and therefore you get hit as you might in a firestorm, but that those who get hit are the ones who have exactly the same problems as the last one that just had an accident. That the markets focused on a set of factors where they learned about how a country quickly can go under and everybody who is vulnerable in that respect will get a visit. And if the first visit produces a disaster, who is surprised that there is more of it? And that explains why we should have gotten to Korea, Russia and Brazil. Russia and Brazil are not exactly in the neighbourhood of a Korea or a Taiwan.

The third issue that is important to address is the sheer magnitude of a financial crisis. Why is it that when a small foreign exchange thing goes wrong, the next thing, the banking system is bankrupt, the economy goes into a recession of 5-10 per cent, the currency collapses by a factor of $3,4,5,10$, you risk being on the verge of hyperinflation, where just a year before, you were the model case of how to manage a 20-year growth experience.

I think there are 3 arguments to bring for the depth of the collapse. The first one is again, financial structure. A banking system is a very important part of how a country hangs together. It may even be a country's neural system. If the banks are directly involved in the problem of exchange, perhaps because they had very large dollar liabilities and therefore a big exchange rate move wipes out their solvency, certainly their ability to lend, certainly their ability to extend credit, that would be a major impact. That is the 1930s story of the Great Depression, and exactly the same mechanisms can happen very rapidly in an emerging market setting where on the liabilities side, very, very large, very, very short term liabilities, can in no time become a bankruptcy issue for an entire banking system, more so if it's unregulated.

I think the second issue here is property rights. You would believe that when you have a country collapse with asset prices falling to $1 / 10^{\text {th }}$ of what they were, and the currency collapses to reduce those prices even further, why is not everybody rushing in to buy themselves a vacation home on the finest beach of Thailand, or a wonderful estate in Indonesia producing palm oil. And property rights is the answer.

In a country where there are no property rights, cheap means nothing. It means it's too expensive. When Mexico went under, the US bond artists, the cannibal funds that go into distress situations, worked on the rule of thumb that 50 cents on the dollar was what you get in any corporate reorganisation. When the bonds failed, if it's less than 50 cents on the dollar, buy it because on the collateral, you make your money. And when the Mexican bonds went to 20 cents on the dollar, all the scavenger funds said, "Wonderful times lie ahead. We're going to buy up all the Mexican debt. We're going to repossess all the collateral; we're going to make a lot of money." And by accident, someone sent a lawyer to Mexico, just to get the details. And they found, yes, it takes 9 years, but nobody ever succeeded. And that was the end of trying to repossess assets, to buy it at a bargain, to believe that in a financial crisis, there is real value to be gotten. 
In Asia, very much that is the issue just as it was in Mexico. The issue is that it isn't worth buying the stuff, because it isn't going to be yours. More so if the judges are for sale. More so if Suharto's family is an integral part of the bankruptcy, who believes you'll depossess them. In every one of the Asian economies, property rights is a dramatic issue. There's no way of assuring those. And as a result, capital is a one way street. It only goes out, or tries to go out, and there's no offsetting arbitrage that comes in to say, "These assets are cheap, let's take advantage". Surely, that has an important implication for how to respond better to a crisis.

The last issue is politics. Under politics, of course, is the question of whether a country will or not subscribe to a serious stabilisation programme. The exchange rate will keep falling as long as investors see the central bank print money. And the central bank is under pressure to print money to save all the president's friends, and the exchange rate responds appropriately.

The only way to stabilise is high interest rates and a tight budget: what the IMF preaches. And the IMF is totally right. Unless it's expensive to speculate against a currency, a currency will not stabilise; until the currency stabilises, there is no prospect whatsoever for the economy to settle down, for people to evaluate risks, and for people to start reconstruction. So I believe the uncertainty of whether the political process would allow an IMF programme to go forward is an essential reason why we have seen in Indonesia so much of a problem, before Professor Schliesinger arrived on the scene and lent his credibility to a government that had none. Of course, he has left Indonesia now, and we have to fear what is Act II.

But the same question was there in Thailand and the government had to fall before the confidence returned. The same issue would be there in Korea, were it not for the huge current account surplus they have now which frees them to pursue their policy errors. So I believe the politics are an important part of the depth of the decline of currencies, and the magnitude of instability and again, reflect on poor management in place rather than on the international financial system.

Let me ask next how to reform the system to respond to this anatomy of the crisis. I think the starting point surely has to be in the countries under attack. And the second issue is how to reform the international environment in which these things happen.

In the countries under attack, it is tempting to just stop the attack. There is no way of hoisting a white flag. That doesn't exist in this sport. But surely, there is a way of signalling that you want to be very different and that you are taking dramatic steps to change the way the country is run. That is the positive way. Or else, you impose capital controls, and that's time out and you say, "We are going for awhile into the Stone Age". I have absolutely no sympathy for capital controls. I am shocked that serious professional analysts have come out with that proposal. It's a crazy idea, it confuses the future, it destroys whatever contract credibility is in place and it solves no problems. It seemingly solves the problem because the exchange rate isn't moving anymore, but it opens the next question of how you return to the international financial system and how much credibility has been destroyed in the meantime. I don't think that anyone has been successful by imposing capital controls in the middle of a crisis and as a result has done really well. Surely Malaysia is getting deeper and deeper into problems and surely not away from them. 
I think that the other alternative to sharply change the course of events is the right way, and my example of that would be Argentina. Argentina, for a decade, committed every single mistake that you can imagine. Every morning, they would wake up the president of

Argentina and he would say, "Is there any, any mistake I have not made yet?" And they would say, "Si, Señor" and he would proceed to do just that.

In the early 90s, Argentina literally exploded in hyperinflation, in a collapse of production, in hunger and food lines in Argentina that had never been seen in the entire history of the country. And that led to the fundamental and profound restructuring of the country: one hard money, a currency board that even today, years later, everyone, every politician, every taxi driver, every housewife supports without any question. Second, a fundamental restructuring of the state, by getting rid of much of it, almost most. And as a result, a deep gain in confidence which one can see today.

Seven years ago, Argentina was a country of old people, where the young were getting their passports, and getting out. And today, Argentina is run by young people who have come home. Who have dynamism, energy and unlimited confidence, unreasonable confidence in the future of the country. I think there is only one precedent, and that must have been the monetary reform in Germany after WW II, where very much the same thing happened, where from one day to the next, a sense of confidence and rebuilding happened.

I think that is the appropriate response to a dramatic crisis as Asia has seen, and anything else is going to be unsuccessful. Anything else is moving the furniture around. Anything else is trying to solve half the problems, leaving the other half for the future, with inevitably a question of where growth is going to come from. And if the growth doesn't come back, then of course fragile political systems will be tested much harder.

So I believe at the country level, we have to be extraordinarily demanding and say there is a chance for radical reform, and radical with a big $R$; and then, the success stories are there, whether one looks to Chile in the past, or to Argentina. And if that doesn't happen, don't expect that it's a small ambush with the financial market that is easily overcome and soon will be back where we came from.

I think any radical reform will involve, quite definitely, on the side of the banking system, a very dramatic rethinking. So that the banks are well regulated, well supervised, well capitalised, and as a result easily can stand high interest rates, and therefore, easily can stay in place as the country inevitably gets tested by events beyond their control or even by domestic politics. To return to Argentina that happened in '95 the Tequila Crisis. Argentina was on the short list for having currency problems. Their currency wasn't devalued, interest rates rose, the speculators left.

The same issue is happening now. Everybody knows the banks are even better. The interest rates are high. Nobody believes there'll be a banking problem in Argentina. The same is true in Hong Kong. The banks are extremely good. The country is hit extremely hard. Nobody believes the banks are going to go under. And the speculators have left. They haven't succeeded. So I believe that the reform surely must include a dramatic attention to the banking system, which is the Achilles heel of a country integrated into world capital markets, something that today is unavoidable. 
It takes me to the last question of how to organise the international financial system. And in particular what to do with the IMF. And there are two ways to go. One is to say that the big problem is that we didn't have enough money. And if we had had much more money, and far more discretion, then the collapses that happened, might not even have happened. The money would have been seen, and people would have turned away from the bank run. They'd have said, why run? Walk, because there's enough money on the shelf. And of course, that is an extremely tempting idea, except that it is an invitation to the process of mismanagement and so "no" to dramatic amounts of money for my friend Stan Fischer. Perhaps that's the way we get him back to MIT.

But what could we do to turn the IMF into an effective instrument? A great effort in the surveillance process, prevention process - I think the emphasis should indeed shift to that area. What can the IMF require of countries in order to qualify them for support? The answer is financial supervision that requires them to have balance sheets that are sound. And that means that the only way that a crisis is an honest crisis: something that is unexpected, beyond your control, and surely, you should be bailed out. If IMF focuses not so much on inflation - not so much on whether you have $3 \frac{1}{2}$ or 2 percent budget deficit, but entirely on the balance sheet of financial institutions and the national balance sheet, and no bail outs for countries that have balance sheets that are out of line. Let's take that risk for the world financial system. Then I think people would learn very rapidly.

I think the IMF would do well recommending to many countries to have a currency board, to get rid of amateur central banks in Eastern Europe, in Latin America, and that would take the exchange rate issue out. The exchange rate issue is gone and the bad banks are gone, it will be much, much harder to get spectacular crises. There will be some, but they will be easily resolved with a lot of money for the IMF.

So I believe sound banks, currency boards, pre-emptive IMF treatment that makes clear that only those who have passed the inspection regularly will qualify for support, creates an environment in which government are much more on the spot. They will not make the world safe forever, but at least it will avoid the situation where a whole region with no terrible finance goes under simply because a little bit of a problem happened and next thing the whole house of cards collapsed.

I believe that whenever we have a big crisis, we have a great opportunity to go the right way. I think the $\mathbf{G} 7$ programme is an attempt to take the wrong way because it's the easier one. I think we ought to challenge the international institutions to be more ambitious. To not plead that they are managed by their member governments and therefore have to participate in their corruption, and that they should take the responsibility of proposing something that is far, far better suited to give us a safe world economy.

Thank you very much. 


\section{DAY TWO}

It's still a great pleasure to be here. Nobody should leave the room under the threat that it gets very formal. I don't really get very formal. The maximum of formality is to have a diagram with two lines. One goes down and the other goes up, and if it doesn't fit in there, then you haven't figured it out. So we have a few of those, and some countries behind. The objective, of course, is to find a simple way of thinking about issues of currency crisis, and ask what are the essential ingredients: both the economic structure, which ultimately is the setting for the demise, and the political economy which is the setting for making the mistakes. That is pretty universal. Whether it is a Lafontaine, trying to do populism in Germany, whether it is an Alain Garcia that tries the same in Mexico, or whether it is called Kim and it is in Korea. In the end they have the same problems and ultimately, mostly the same result. I add mostly because in a very rich country you can afford to do very bad things very very long. (That was not a comment on Peru.)

I want to focus today on this old new crisis distinction in a little bit more formal way, and ask what the old ones looked like, and then focus on Brazil as the new kind. This is a crisis, for some it is over. Stan Fischer quietly spent time here on academic issues while, perhaps to suggest there is no Brazil problem. If he were in New York, people might be worried. But perhaps there is one and it is unresolved and what I propose to do is look at that as an example of the new crisis. And the issue is, can a country bear to live with an overvalued currency and a high real interest rate to keep the money coming forever? And the answer is, "No". And if you can't do it forever then one of two things happen: either a miracle or a currency crisis. And miracles happen, but often not in this context and not in time and that's the Brazil issue of course.

Well getting ahead, let me talk about the slow motion crisis, the typical developing country crisis: first of the kind that one had until the 1980s. And the big question of where to draw the line between the old and the new ones.

My reading is that certainly the Mexican crisis of '95 was entirely the new crisis that had to do with a large dollarised short-term debt, with an average maturity of a few weeks. Shortened and shortened in a run-up to an election, in a desperate attempt to get to that election without a problem. And if you shorten your maturities then you will find some creditor who is willing to stick their neck out, because somehow they think a short maturity means that they can get their money out. They haven't figured out that a short maturity means that all together they cannot and when one tries nobody will succeed, unless there is a bailout and that turned out to be the case.

Another candidate for drawing the line would have been 1982, where we had defaults on emerging market debts across the board and that appears in that context. So, somewhere either including '82 or definitely Mexico '95, that's the new style of crisis, that when it comes happens very, very fast, very, very big. And before you have dull crises, that sort of are local, that are uninteresting, that aren't traumatic, that are a relief when they happen, finally, except for the minister of finance. And when they happen, they bring the answer: a currency depreciation which is badly needed to get back to normality, even though politically they are very controversial. 


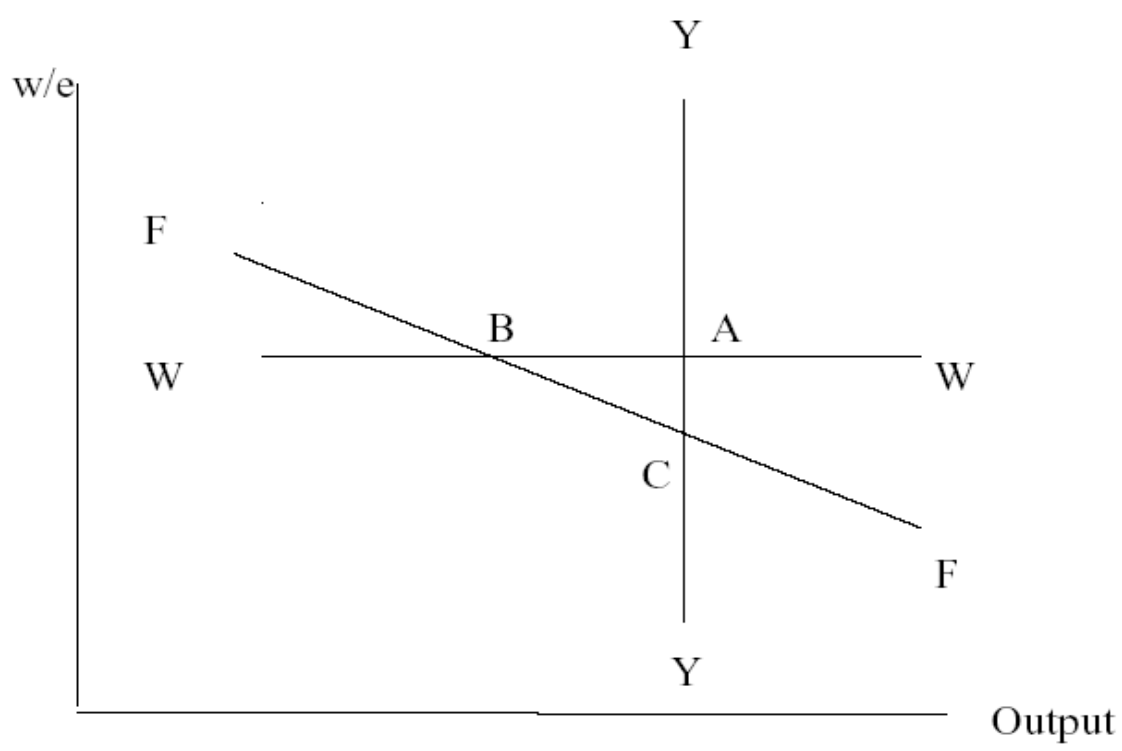

Figure 1

Here is my favourite way of looking at these old style crises: I have w/e, that's the wage in dollars and that measures the standard of living and that also measures competitiveness [Figure 1]. The wage in dollars is one of the key variables, both in how the economy functions and in the political economy. How the economy functions because that's competitiveness: if the wage in dollars is low, then a country has a cost competitive position and has a competitive real exchange rate. Wage in dollars is the real exchange rate. And the other variable is output. And that means, among other things, employment, and that is, of course, a very political variable.

The point of the diagram is that the three lines don't intersect. And that is, of course, what makes something interesting, that is the added of politics. I have as a vertical line full employment: there is some level of output at which we have full employment. I have the downward sloping line that is external balance, a higher level of output, higher imports, deficit: in order to gain competitiveness would need a more a lower wage in dollars. Points above into the right are points of deficits, because either output is too high or the wage in dollars is too high and therefore it is a deficit. And points below are points where you have a surplus because you are competitive, or output, and therefore imports are compressed. The normal economy is full employment and external balance and that would mean, Point $B$ is happiness and that is where you would be, unless you had a way of big reserves, the IMF, the World Bank, Citibank, lending you the money to finance external deficits.

But I have added a third line, the flat one, a level of the wage in dollars, which is political. Call it "social peace". If the wage in dollars was less, then you'd have strikes, riots, disruption and the point of it is, the wage in dollars, in the way $I$ have drawn it, is not compatible with both full employment and external balance. And the moment we have the three possibilities, then we'll say, well, where are we going to be? 
And Point A is, of course, the Latin American equilibrium. Your social peace, that is the most important thing, and second your full employment, that is very important, and third you find someone to give you the money to run the deficit. And as long as the money is there, you happily run the deficit and, then, one day, the money runs out. And then you have two choices: you can have a contraction of economic activity, perhaps through a fiscal austerity drive, that takes you to Point $C$ or through tight money and at Point $C$ you have established external balance. What else can you do, you don't have the money to finance the deficits - but, of course, now you have unemployment. So, worry there!

Or you could go to Point $B$ and you have a big devaluation, and a big devaluation of course, solves the external balance problem but, of course, it also means that there is a lot of unhappiness. The minister falls, there are strikes everyday and, neither $\mathrm{C}$ nor $\mathrm{B}$ are lasting situations. Because the politics of either is that they are unbearable. So what will happen? What happens is that you keep going in circles. After a crisis when the money runs out, then you go to $C$, but you don't really like $C$, so you try and get some money and if you find it you go back to A. Or you get an IMF mission because somehow this employment is too much, and they persuade you to take off trade restrictions, devalue and you go to $B$. B is the IMF equilibrium. But IMF equilibrium is not really a lot of fun, so you give in to wage demands and that means the wage in dollars starts rising and you get back to social peace, but the deficit comes.

In telling the story there is obviously no escape from going around those three points. The only happy days are the days where someone gives you money. But you always get money. What is available for Latin America has expended for the last hundred years and with great regularity, there are currency crises. The situation is a little bit worse than I have drawn because if you keep borrowing, then of course, you built up interest liabilities. And as a result the level of competitiveness or output that is consistent with external balance, that negatively sloped schedule, keeps shifting to the left and your problem of social peace becomes harder and harder, unless wonderful things happen in an offsetting way to make you more competitive, so that at the same wage in dollars your costs fall through productivity growth and you will get ahead. The more the interest burden rises and productivity growth isn't big, the more you get away from an equilibrium situation and the more you look like a chicken, going around this unemployment, devaluation, inflation, brief moments of happiness, followed by an average period where the economy is mostly macroeconomic, because either it is fighting an inflation or it is doing the next devaluation to come out of the loss of competitiveness of the previous one.

All of this has no capital account in it, other than the sense that someone gives you a chunk of money that you spend. But no linkages between domestic interest rates and the amount of money that comes in, and no financial crisis. It all has to do with the goods market and the current account and how to pay for the excess of spending over income, which is what life is all about, at least in Latin America.

The slow crisis is that you know that if you sit at a point like $A$, and you spend a billion and a half every year, and you only have five billion you divide one by the other, it is going to take that long and it never it is really true that you get that long, so you know that within two years this policy isn't going to work. And you may surely try and lengthen it. You do that by putting tariffs and that is going to shift your BB schedule, 
your external balance schedule, the negative one, a little bit. But it doesn't really work so well, because the tariffs also reduce the standard of living so they give you wage demands.

And the wonderful thing about this is you can keep talking, because when you have three points that don't all intersect, then you have three possible equilibria. And you are never going to be able to stay at any one for any period of time, because unemployment is impossible forever, except in Europe. And low standards of living are impossible for any length of time, except in Russia. And $A$ is impossible for any length of time, unless the IMF gets more money to keep everybody there.

That is what international macroeconomics was about before we had opening of capital markets and before we had domestic deregulation and before the capital account became the principle actor in the story. This one is entirely about competitiveness and the standard of living, the play on that. And the new one is entirely about the balance sheet and how to get the guys to keep rolling and bringing the money and to keep the music playing which is an entirely separate issue. These stories are still there. A big devaluation is still a big issue in terms of the standard of living and politics, we see that in Indonesia, or we see it in Malaysia. The issue of unemployment is still there in a very big way. Look at Korea where the huge unemployment is a major obstacle to the restructuring that the government should, and might even want to be doing. But it isn't the principle actor; it is the extra complication in the background. And the principle story is really focussing on the balance sheets and what are real exchange rates, interest rates, exchange rate expectations that come into play, and threaten that all of a sudden the money wants to be leaving.

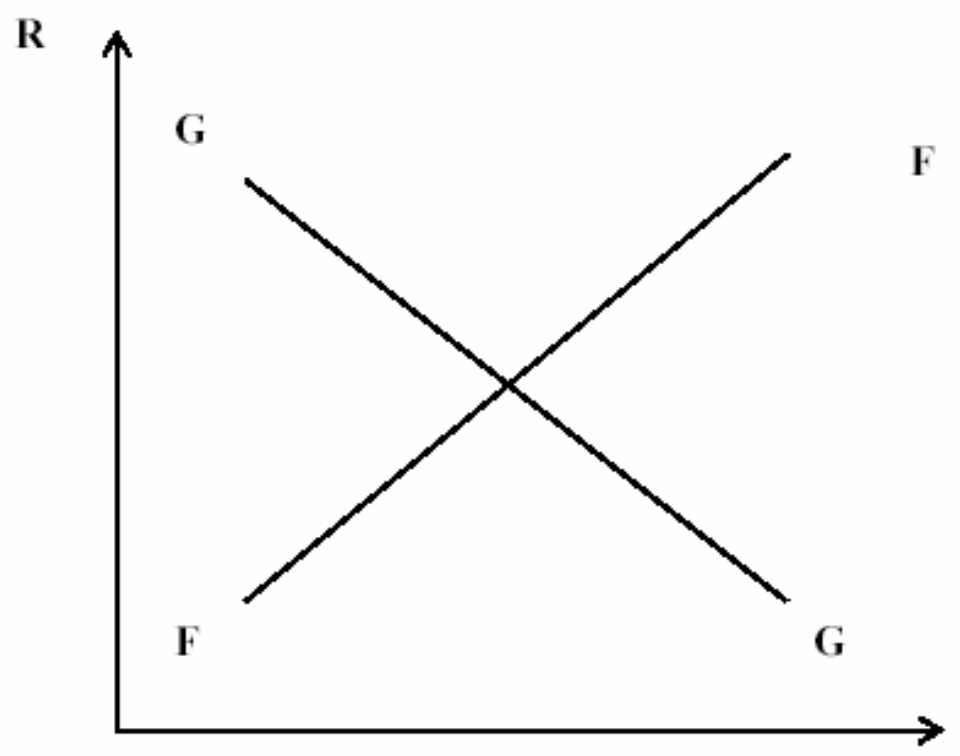

Figure 2 
So let me focus on that and the useful ways to change the axes, but still have one that goes up and one that goes down [Figure 2]. Now, because I am concentrating on the capital market, the real interest rate appears. Little $r$ is the real interest rate and big $R$ is the real exchange rate, and we are going to look at two equilibria, one in the goods market, I label it now GG, combinations of real interest rates and real exchange rates, such that we have full employment or whatever you like to call goods market equilibrium. Points to the right, we have a real exchange rate that is too appreciated, too uncompetitive to support full employment, or real interest rate that is too high for the given real exchange rate to support full employment. So anything above and to the right of GG is a bad situation of unemployment, anything below is happy.

We have FF as the balance sheet line, or the balance of payments line, or the capital account line, however you like to call it, and that will depend on the real exchange rate, because if it is very appreciated then that is a concern. It invites the thought of real depreciation and therefore a loss to investors. To offset that you need high real interest rates. So, points down and to the right of FF are happy points where the investors get paid. They get paid for exchange rate risk they don't even see or for whatever risk they see, they are more than paid enough and therefore money is coming in plentifully. And points above and to the left are situations where investors are not paid sufficiently. They see an appreciated real exchange rate, they say here is a problem in the making, and $I$ am not being paid enough in real interest to have exposure to that risk. I am leaving. And the leaving may be fairly gradual at the front in or it may just be in incipient tendency that invites the government very quickly to change the real interest rate in order to keep the music playing.

In the face of the new style crisis, keeping the music playing is all-essential. You might think of Mexico in '95: an election in '94 when the story really started. The crisis was December '94 into' 95 - elections in Mexico every 6 years, a great event, and how to make that a happy event: overvalue the exchange rate all the way on, in order to bring inflation down, in order to raise the standard of living. Hope that the employment effects don't come too fast. Have a glorious election, and then hope that nothing happens. Hope that nothing happens, of course it is never right, because in Mexico every sixth year, is a year of a great catastrophe.

Let me show you my favourite picture that goes with Mexico [Figure 3]. I let you guess where the election years are in Mexico! 


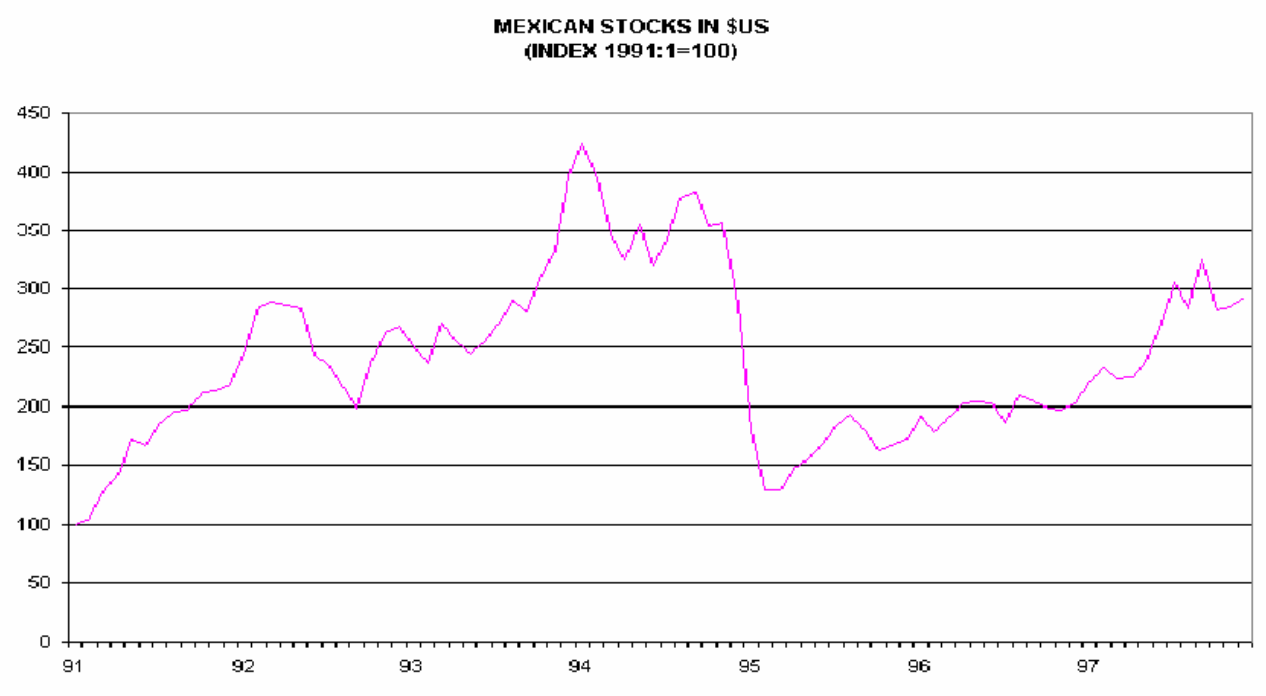

Figure 3

And you're right, it has to do with the verticals. There is a little confusion in one of the transitions. And there is an interesting question about the year 2000, the next election. Is that a flat for a moment and is it going to rise again, in which case you get a vertical in $\mathbf{2 0 0 0}$, or has someone just learned the lesson? But, I use it to say, that in terms of my previous diagram, real exchange rates for a while may be appreciating and then the increasingly become a problem and how do governments respond to that increasing problem. And that takes me back here.

Investors are very, very happy to stay to the very last minute. They ideally want the advantage of the very high interest rates that are being paid in the run up to a crisis, and leave the night before, get the last train out, the last ticket being written by the Central Bank. And if that is done successfully, then of course they have excess returns, because they are being paid $40 \%$ real, and they get out. And the day after the crisis they come back in and collect again huge returns as in the aftermath of a stabilization, interest rates are high, inflation is being fought, the exchange rate has over-depreciated. Wonderful money is made. And if we always get it right, then of course we become very, very famous. That is the game and a great illusion of course, is mostly, that you may not be able to get out, except if you really understand that the IMF is always there to write extra tickets when the Central Bank has none left. Then you're going to always be paid excess returns and you never have to worry, and Russia spoiled that fun.

Here is my shaded area, sort of the typical country that has a problem. The real exchange rate has appreciated; it will have appreciated typically in the process of trying to bring down an inflation. The exchange rate was fixed or a crawling peg that moved too gradually, too slowly, and because it moved too slowly, prices at home kept rising more than the exchange rate depreciated. Competitiveness gradually has been lost.

That loss of competitiveness is starting to show in a declining growth. Not immediately, because in the first instance a loss of competitiveness is really a rise in real wages. And a rise in real wages raises demand, and a rise in demand raises employment, and the minister is smiling every day because it is giving people a really good life. But then over 
time, of course, it comes to competitiveness that you can't sell the national output abroad that imports become very cheap relative to those domestic exports. Then it goes both to output and to employment, and then it starts becoming a problem. That clearly is true at my shaded point there. But it is also true that the rest of the world says we are seeing a real appreciation and this is uncomfortable because it is already showing in growth; it is already showing in an external deficit, and "Am I being paid enough to be here".

As they ask that question, the Minister of Finance comes and gives his speech to say that while doing very dramatic reforms, we have even thought of privatizing our state enterprises, and we're looking forward to new corporate subsidy, and I don't know what. Just to keep the money rolling and coming. Money that is necessary because on the external side, you need to finance what is now a current account deficit and you certainly need to roll over the debt.

These investors will say two things: "I am happy to stay, but I need more. Because my exposure is more, because $I$ see that your no-growth situation is a problem. In the end you want to escape from it, and I don't want to be there when you try to escape. I need to be paid more. And I cannot make long-term commitments because this is not a story that is going to last long. I want my maturities shorter than your story." And that is, what we see over and over again, that as you move gradually into the perception that there is a problem, the maturities go down.

How much can maturities go down? Unbelievably, Mexico had an average maturity of its public debt that was less than two months. That means that Mexico was basically financed in the overnight market. The difference between two-month average means that half of them were one week and the other half was two months and a quarter. Means the distance from here to Christmas, from the maturing of the whole public debt and the need to roll it all over because paying off is inconceivable. The shortening of maturities is a very systematic feature of a situation whether the creditors say, "Yes you can have money but I want to be able to leave as I perceive a deterioration. Pay me more, because I don't want really to have the angst. The maturity is just so I can leave, the paying is so I will stay." What happens here is that as the real exchange rate appreciates the interest rate goes up, the maturity shrinks by a third dimension and my balance sheet become increasingly a problem.

But the economy does not get any better. Because the higher interest rates, of course, now make the growth disappear more and more, and as the growth disappears, the political prospects in an election - this has to do with democracy, right? That's why they get all the money, that they are democracies - the bad guys could win and that means shorten the maturity. Don't have your debt mature after the election! That's a problem. Raise the interest rate because you need to explain afterwards why you are there.

So very, very systematically in every one of the Latin American crises you really see that same pattern. It starts with a real appreciation that is the counterpart of an inflation/stabilization process, then the real appreciation is really there, the disinflation has succeeded but the real exchange rate now is the problem. The government is unwilling to deal with the real appreciation problem by any of the known ways: a flexible exchange rate, a devaluation and aggressive crawling peg. They don't want to, because everybody is happy. Because they suddenly have high real wages. 
And then they say, "Never", and that is the magic word. Once you have said "never", you are committed to the bad mistake. And then you start paying for it. With maturities and with interest rates. The more you pay with the interest rate, the less the growth, the worse the budget, because you have a high debt that gets rolled at high interest rates, and therefore the politics is going to get worse, and you paint yourself into a corner where it would be a sheer miracle if in the end you could get out. Mexico is a case study of every six years doing exactly the same, and everybody now knows it. Why didn't they know it the last time? Well, they had not seen the picture with enough verticals. But now they know it is not going happen before the election, it is going to be the week after. The week before the election, everybody wants to leave and that is when your currency crisis starts, that is when the Central Bank gets rid of all of it reserves, but doesn't tell anyone. A little bit of smoke and mirrors is essential there, but so far everybody gets through the election.

Very, very systematic, happens every time in the context of disinflation - is very much the Brazilian story. I emphasize the two ways or I should say, three ways, in which it is unsustainable. The first is that you lose economic growth, with very high real interest rates, and an uncompetitive exchange rate. You can have whatever real exchange rate, but then you need really low interest rates, to offset it. Or you can have very high interest rates, but you need a super competitive exchange rate to keep economic growth going. If both are in a wrong place, then it is a question of time. So from the growth side, and therefore from the politics side, incompatible.

Second, on the budget side, in many situations the high real interest rates are unsustainable, because you have a big public debt and the public debt is growing at 40$50 \%$ interest rates that becomes the growth rate of the debt. And it takes only time before that debt is unpayable. There is, of course, from growth an influence on the budget, which reinforces the fiscal problem. The third is the financial institutions, which have of course no way of having their loans paid at these real interest rates and, as a result, experience a gradual deterioration in loan quality, and sort of, gradually go bankrupt.

But as that process happens, something very, very important gets into play. In this economy, where real interests are very, very high, large companies and banks find out that you can borrow off shore in foreign exchange for almost nothing. And that means the locals bear the exchange risk rather than the foreigners. Foreigners are happy to lend at Tokyo-plus-two, and those loans are taken. Suddenly the domestic banking system and the domestic corporations, to get away from these very high real interest rates, that are rolling at home, reflecting currency risk, take on foreign liabilities. And those foreign liabilities are supplied at almost nothing. And they allow, at home, a different reality. Suddenly, at $3 \%$, you can buy beach houses to infinity. You can give loans to infinity.

So we have the two things: we have one side an exchange rate that is in the wrong place, and an interest rate on domestic liabilities that starts reflecting exchange rate risk, and on the other side, we have those who have access to the world capital market (large firms and banks), borrowing in foreign exchange, getting their hands on a gigantic amount of money, which they cheerfully lend out at those high domestic interest rates, absorbing in their balance sheet a currency risk. 
They say, "Well, this is glorious. I am borrowing at $2 \%$ and I am lending at 40 . I am making money like crazy and I am going to have another bank." And so you get a proliferation of banks as the way to go to the world capital market. Get a lower money and lend it at home. How long can that last? And you can do that for two or three years. But when you have done it, you have packed the whole financial system and the large corporations with a dollar denominated debt or yen denominated debt in a situation of an exchange rate that is in the wrong place.

The only reason this happens is because everybody says, "Our government is totally committed to this exchange rate and then never let going to let it go. And I know those guys, I have talked to them, and they are actually my second cousin; and we pay Him." (They don't say that, but that's true.) So it is deep confidence of enough people that this exchange rate regime will stay and that therefore, borrowing in dollars and lending at home and making a spread is money you are making. It's yours, and you are stupid if you are not doing it.

It is totally essential that it need not be everybody. They may also be a lot of people who don't believe in it and think they're going to make losses. What matters afterwards is that some people have done it and they go bankrupt, and that the country has done it and is going bankrupt on it. That is the story of whether you look at Chile in the late seventies, a fixed exchange rate, Pinochet said, fixed 3.8 forever, and everybody says, when Pinochet says "forever", it is forever, because he is forever. And happily they were worrying and of course, when in the 1982 the currency went they all went with it.

Or whether you look at Mexico, where the government did it itself, because they could not sell peso bonds anymore, or the Mexican banks did it big time, because they believed in the government, or the large Mexican corporations did it, because of the irresistible fact that when the domestic interest rate is $40 \%$, and the rate in foreign exchange is 2,3 or 5, where do you go? You go for the 2, 3 or 5 and you say, "I know they are not going to do anything", or, "I know they are not doing anything soon", or, "I know that before the election they are not going to do anything." Whatever rationalisation you need to take that magic potion. That is what happens, and that moment, we are having a balance sheet that has lots of dollars in it.

Now, the complication, of course, is that the foreign loans are not ten-year loans. It is true that they are 3,4 or $5 \%$, but they are 1 or 2 month loans. So we have a balance sheet that is enriched with foreign liabilities in foreign exchange and short maturities. And, as a counterpart, we have at home a scene of real appreciation that is unsustainable and a real interest rate that is unsustainable. And so the only question is: When will the two meet? And something that cannot last forever, there is a theorem that says, ultimately will end.

What is important is that the problem has to be identified, not the little circumstances that bring the end. That the election is over, often is a good reason. Or, that some commodity exports don't do so well, and therefore someone cannot get the loan renewed and that word spreads and therefore others also can't, and in no time it is a disaster. So I wanted to emphasize here the systematic way in which the high interest rates on domestic liabilities encouraged the taking of the foreign liabilities, and how the real interest rate rising is the offset that foreign investors require to roll the debt positions and that the shortening of the maturities is another dimension for the foreign investors to reduce what they perceive as their risk, and to increase their flexibility. 
The worst possible thing, of course, is that the lenders become more flexible just at a time where the debtors would want very long horizons. And this world here is run by the creditors. The creditors may lose in the end, but they certainly try to the maximum, (a) to be paid on a way there and (b) to have the flexibility to make a run, and that is how we get the bank run, and third to find someone to bail him out, so that they can walk away with the high interest rates and not have made the losses. That is the IMF system, of course.

Let me, with that setting in mind, look for a moment at Brazil [Figure 4]. Brazil in my judgement is the next candidate. The first thing is, where is the problem? I am looking here at the least controversial way of showing Brazil's real exchange rate. I am just looking at Brazil's wholesale prices in dollars. I am not trying to have a multilateral real effective exchange rate weighted by Brazil's trade with every piece of the world. I'm just saying prices, in dollars, in Brazil, what has happened?

\section{BRAZIL: PRICE LEVEL IN \$US \\ (Index 1990=100)}

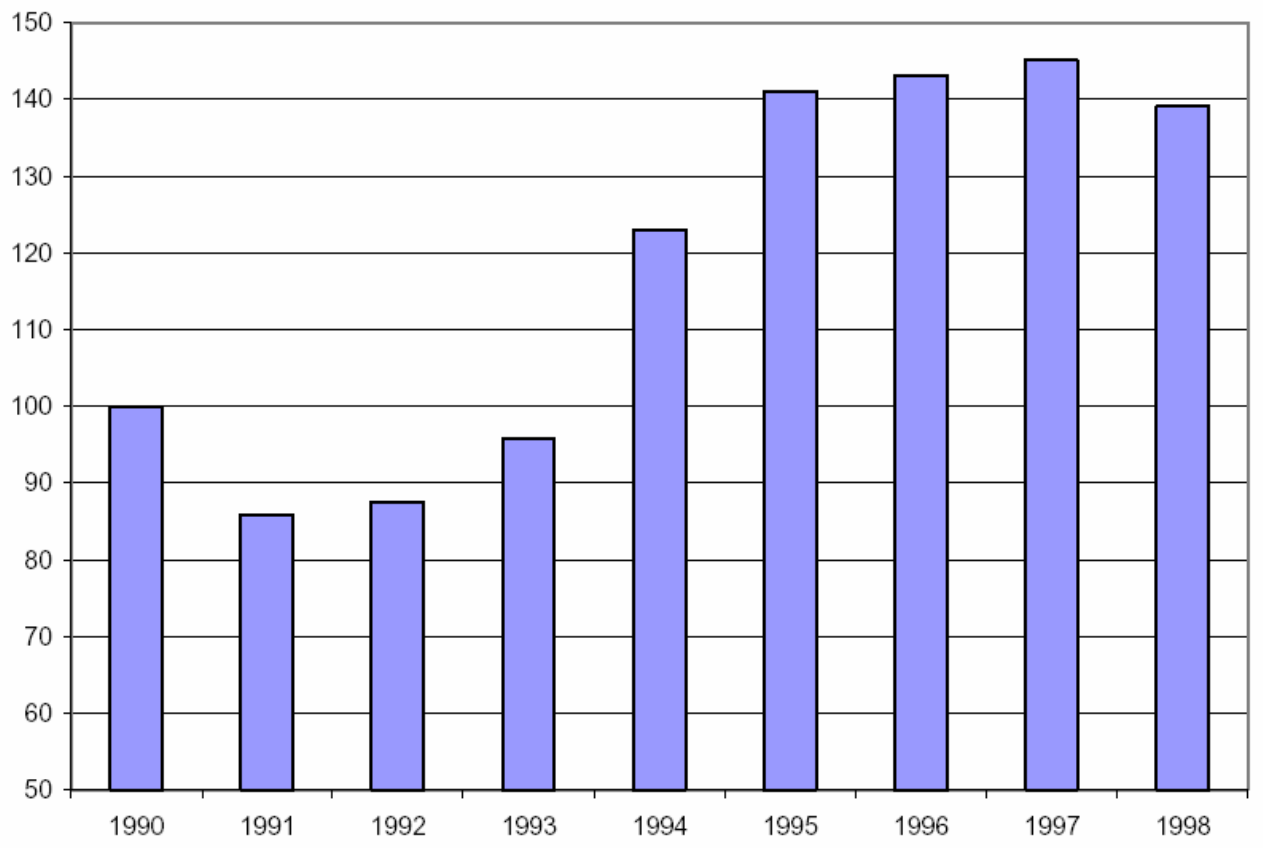

Figure 4

You notice that in '94, you have a very sharp rise of Brazilian prices in dollars. '94 is the stabilization of inflation; at that time hyperinflation stopped, the exchange rate stopped depreciating, in fact, it appreciated for a while, even as domestic inflation came down from a monthly rate of $25 \%$ to a monthly rate of $2 \%$. But a monthly rate of $2 \%$ is still almost 30\% inflation per year. And that is the post-stabilization here in Brazil: substantially $30 \%$ inflation. And the following year was still $10 \%$ inflation, and the exchange rate was fixed. 
So, Brazilian prices in dollars very rapidly increased by $40 \%$, and that happened fast within the year of stabilization. And since then, they have had a crawling exchange rate, accompanying the rate of inflation, and have not lost much in terms of competitiveness, but the $40 \%$ they had at the front end is still there. You can now quarrel about how much is the exchange rate overvalued, and there are two views. One view is that of the Brazilian finance minister, who says that there has been dramatic productivity growth, and that must be taken into account when looking at Brazil's competitiveness. But he doesn't have to have productivity growth if it doesn't show in prices, right? If he pays it out in wages, then he has happy people, but it doesn't make him more competitive. This picture here suggests whatever productivity growth was there, wasn't enough to keep down prices in dollars in Brazil.

There is another argument that history is irrelevant. The central banker who has a Harvard PhD in economics has said that Brazil is a new country and therefore any historical time series are irrelevant. It leaves you speechless, so I'll leave it just at. And there's a third view - that we have seen that for a century, that there is nothing new about it, that it happens systematically in the context of stabilization. The easiest way to get inflation down is to have a real appreciation. And when you have real appreciation, you have a problem. And when you have that problem, central bankers always say that these are the wrong numbers to look at. I find you some other number that you should look at. But if you look at wages in dollars in Brazil, it's even worse. So what should I look at? Well, he says I should look at the prices of internationally traded goods. All that has nothing to do with Brazil. Our basic problem in Brazil is a big real appreciation.

Brazil is an economy where we have a big fiscal problem, and a big debt problem. We have an enormous Ponzi game on the external side going, and the question is whether investors will stay with it, or whether they will increasingly run away from it. Let me show you the numbers on Brazil so we have a background for the discussion [Figure 5]. 


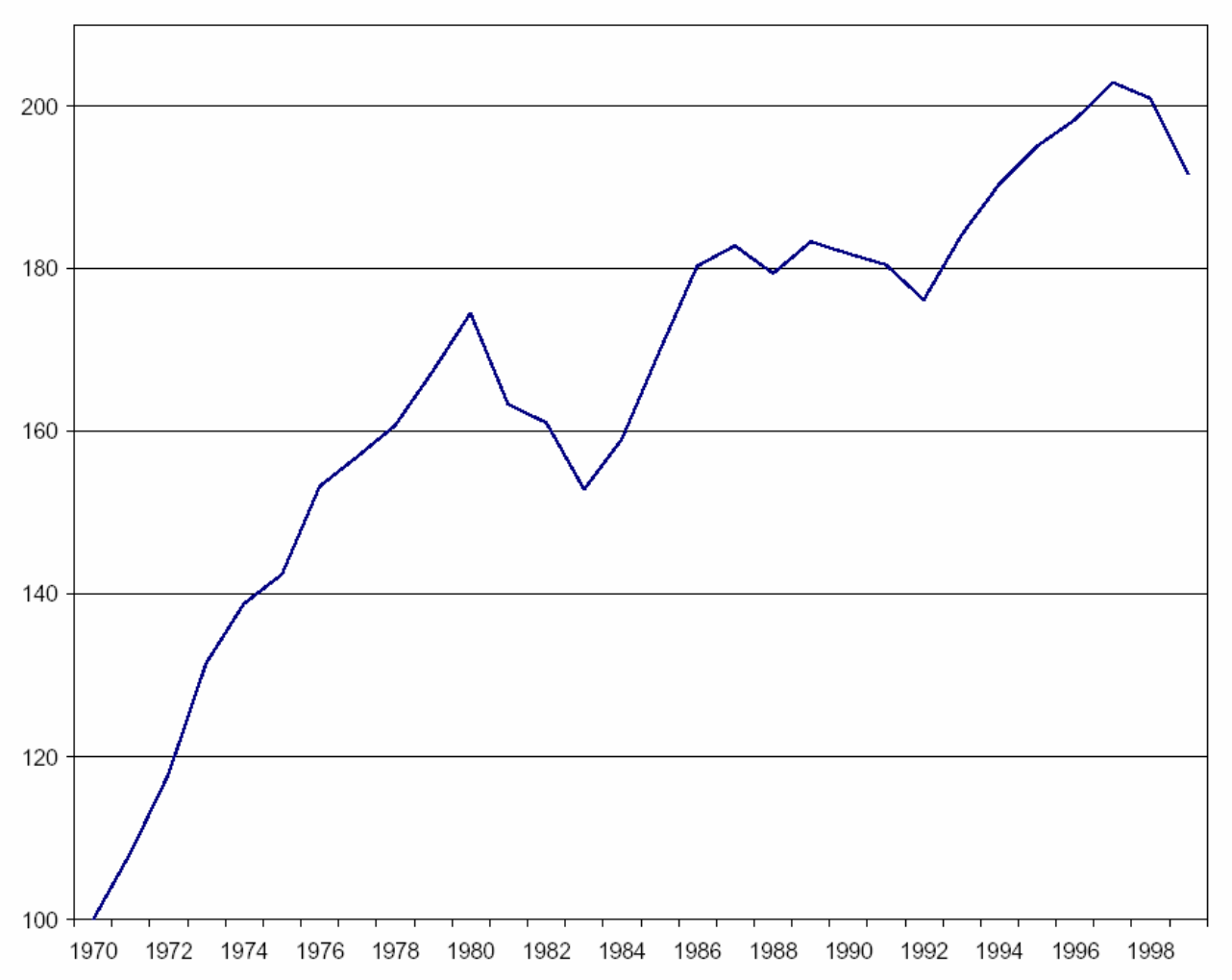

Figure 5

Notice, on growth, that it has disappeared. If you took a longer time horizon, Brazil's per capita GDP has not grown over 20 years. So, there is a real growth problem. Before, from persistent mismanagement of macroeconomics. Now, from the problem I described before: a real appreciation, and high real interest rates to keep the money coming. My measure of the real exchange rate has a real appreciation of some $30 \%$, which is big. And the real interest rate is $\mathbf{3 0 \%}$, which is big. So, if you put the two in an economy, then you should expect to get very little growth. Brazil still had $4 \%$ growth. Where did that come from? Well, Brazil had a privatisation programme, and all the governors who privatised all the local public utilities took all that money and spent it. So, populism populism kept the economy growing. Why? Because '98 was an election year.

But notice, for an election year, this is very little growth, right? A good Latin American election year has 5\%, right? But, the real interest rate was so gigantic, and the real exchange rate so over-valued, that even with furious government spending, you barely got $0.4 \%$ growth for ' 98 . The inflation rate is gone. That is the exchange rate policy. And, of course, by now, the increase in recession, so inflation isn't a problem, and everybody says, "The good president Cardoso stopped inflation, and he has privatised". He has privatised. What happened to the money? And stopping inflation...is it really over if the real exchange rate has appreciated so much, and is left as the next problem? 


\begin{tabular}{|l|l|l|l|l|}
\hline $\begin{array}{l}\text { Table 1 Brazil: Public Finance } \\
\text { (Percent of GDP) }\end{array}$ & 1995 & 1996 & 1997 & 1998 \\
\hline & -0.4 & 0.1 & 0.9 & 0.1 \\
\hline $\begin{array}{l}\text { Budget Deficit } \\
\quad \text { Primary } \\
\text { Actual }\end{array}$ & 7.2 & 5.9 & 6.1 & 8.0 \\
Debt & 29.9 & 33.3 & 34.5 & 42.4 \\
\hline \multicolumn{5}{|l|}{} \\
Note: negative numbers refer to surpluses \\
\hline
\end{tabular}

You see a glorious budget deficit [Table 1]. 8\% budget deficit is not small. Much of that is debt service, because if you have a good-sized public debt, and you have a real interest rate of 30-40\%, it costs a lot of money. And I return to that issue, because the miracle, if it happens, is to get those interest rates down by an outbreak of confidence. There is a good-sized current account deficit for an economy that isn't growing. Think of a very substantial compression of imports, surely any investment goods. Nobody is investing at $30-40 \%$ real interest rates. Those are the interest rates on government paper. The interest rates from banks, real, are far, far higher than that.

We have an external debt that is relatively small, and we have a domestic debt that is small, because four years ago the previous president wiped out the public debt by having a hyperinflation with fixed nominal interest rates. So, this is a new public debt four years old, and rising - and rising rapidly.

So, here is our typical new-style crisis. New style, because the whole issue is to keep the debts going. Brazil's external debt is $\$ 100$ billion with an average maturity of 3 months. And Brazil's internal debt is probably dollarised, and has a maturity of something like 4 months. And that means that every day is an important day to keep the music going. You pay a huge real interest rate to keep rolling this domestic debt, and the foreign banks, because of Asia, are very intensely concerned to get risk off their balance sheet, because risk means that their stock prices are low, and low stock prices means that the stock options of management are worth very little. So, they want to get out.

In Brazil, the music kept playing, because the key issue was that the president should get re-elected: first that he should get a constitutional amendment, to get re-elected, and then, in the election actually to get re-elected. And that provided the continuity that everybody knew nothing bad was going to happen, until the election. And that whatever you could do by moving the furniture, they would do it, to keep the music going till the election. 
It didn't quite work, because everybody said, "It's true that until the election, nothing happens, but the day after, something really bad could happen. Like, they could devalue to get the monkey off their back." And you don't want to be there, so you have to leave before the election. Brazil had huge reserves -- 75 billion dollars - and they lost essentially, 40 billion dollars in reserves, on the way to the election. So, they were forced to go to the IMF before the election. But the IMF was very gracious. They said, "We like Brazil. And we want to support Brazil, because the alternative candidate was a Marxist, so the US Treasury had a bid interest in it. And we want to support Brazil, because we don't need an international financial crisis, and our banks are in there too. So, this is different from Russia. We want to avoid that this blows up before the election."

The IMF announced that it was totally willing to give Brazil a big package, and the investors said, "Well, then we can really hang around." But the banks were still uncomfortable, because they say, if your long run's off, don't roll it over for 3 months, because you are really not sure that this is going to work. So, for Brazil, capital flight substantially continued at the pace of 5 billion dollars a week, running down the reserves. Brazil's Brady bonds fell very, very sharply because now, you were coming to the end of the good news, and bad stuff could be happening. The Brazilian government, quietly, not letting anyone know, bought between 6 and 10 billion dollars of its own Brady bonds, which today are shown as reserves, although, of course they are totally unuseable.

So, every smoke-and-mirror trick in the book was used, and the IMF everyday was saying, "The money is coming. Do not worry," even though Brazil had never said publicly that they would actually do some adjustment programme that would justify the IMF money. But, something else was done, very important, and ultimately a big issue, that in the discussion about Brazil's problems, the Brazilian government trained the investors to say, "The exchange rate is not a problem. The budget is." The investors all became docile, they would say, "A fiscal problem that needs to be addressed, the exchange rate, not."

For the IMF, that was extremely congenial, because they do not want ever to be seen saying, "A country has to devalue." Why? Because the Wall Street Journal would go crazy. And, the adjacent country, Argentina, would be a fantastic problem. So, the IMF is totally happy to say Brazil has a fiscal problem. They don't have an exchange rate problem. As if you could cut the budget deficit, and sustain full employment at an unchanged real exchange rate. And so, the IMF essentially bought into the Brazilian story, because it was politically convenient. In that way, accepting that Brazil, with a fiscal correction (if it happens) would get a recession and might stay in that recession for a long period of time, but the exchange rate was outside the debate. And if the exchange rate was outside the debate, then confidence in the exchange rate might be stronger. And if it's stronger, then the interest rates could come down, and then the fiscal problem would go away, and then if nobody ever looked at the growth issue, then everything would be alright.

That's the script that is being enacted now. A president has done a proposal of a $3 \%$ of GDP budget correction. There is a major issue of whether it actually happens. It involves mostly taxing old people and tricks like that. It's supposed to happen over the next three years. The congress is balking at it, but that is on the table and the IMF money has arrived, and now the bet is on whether there is a significant outbreak in confidence. People saying, Brazil is on the way to doing things right. And you ought to 
get in there, because you get $30 \%$ and the exchange rate isn't going to be a bad surprise, because the IMF programme says, "Don't change exchange rate policy." Over time, the gradual 7\% depreciation that they're doing over time, piece by piece, wills back some competitiveness, and if you hang around, you could have 3 wonderful years of earning excess returns, under the umbrella provided by the IMF.

The other view is that Brazil is going into a deep recession. That that recession is reinforced by the fiscal contraction, and that in 3-4 months, we're looking at something that cannot last. And that there's a theorem that something that cannot last will ultimately end pretty fast. And then the capital flight starts again, and if it does 5 billion a week, then you have a month before it's over. So, carnival is really when hunting season starts, because either you have a collapse of interest rates, because everybody says, "We love Brazil. The problems are solved. The government has done 3\% of GDP in measures, of which they implement $1 \%$, and that's enough. Never mind the other $7 \%$ budget deficit. The interest rate has come down. The growth isn't so bad. And you can just muddle on. You'll be vulnerable forever, but you can muddle on. And you don't have a lot of growth, but who cares?"

Or, people say, "In Brazil, no growth is culturally totally unacceptable, and in time, fiscal measures don't happen. In time, this balance sheet is getting worse and worse. Leave while you can."

So, I think Brazil is a wonderful example of the mix of the new and the old. The new is there with very, very short maturities, with people waking up every day to check whether Brazil is still there, because they have their money in there, with extraordinary amounts of interest, while it's okay. With the IMF umbrella to put a lot of money on the shelf. To write tickets on the assumption that if people see the tickets then they stay rather than leave. With the politics behind it that we have a totally unsustainable macro equilibrium, in real interest rates and real exchange rates.

A very, very important extra point that comes out of a study of two MIT students: Goldfajn and Valdes. They ask the simple question, "When you have a large real appreciation, what is the probability that it sort of gradually goes away?" Gently and gradually, rather than with a collapse of the currency. And they looked at the probability for a 5\% real appreciation, and yes, they sort of go away. And they looked at 10 , and they looked at 20 , and they looked at 30 . And they found that anything above $25 \%$ real appreciation always ends with a collapse. Well, Brazil is well above the $25 \%$. Therefore, by their research on 40 years of exchange rate regimes, the probability that this will work is zero. The answer from Brazil is that Brazil is different.

So, here is my next crisis. It has all the ingredients from the politics of how much fun it is to have a disequilibrium real exchange rate, to how to finance it. And the bottom line of it is that, of course, the real economy does not do well when that game is being played. An economy like Brazil having $\mathbf{0}$ growth in per capita income on average for 20 years is a scandal. Seeing it as a democracy surely is wrong, because next door is Argentina doing it perfectly right with an average growth rate of $6 \%$ with aggressive restructuring, with aggressive regime change, "We're saying, we're going to get out of the rot".

Here, the lesson hasn't been learned here. And the hope, or the scenario, where everything works out is that you have $2 \%$ growth for the next 10 years, which, for a country with near $2 \%$ population growth, is another decade of no growth in per capita 
GDP. That it should work would be amazing because a balancing act like that is, of course, vulnerable. You need, everyday, very, very sunny weather because the slightest thing goes wrong with that short debt, a problem comes. But it may be even worse, that within 2-3 months this has blown up, because the real exchange rate is too central to the economy, and nobody really believes that at this real exchange just doing something on the budget is a viable strategy. 


\section{DAY THREE}

It's a great pleasure today to try and defend myself as I disqualify some remedies as dumb, even though a distinguished colleague of mine has advanced them and many people feel that finance must surely not be allowed to interfere with daily life. There is in everybody a populist streak that somehow believes that maybe money should be done in moderation and discretely and not at the expense of others and surely taking it to the point of destroying in higher economies is utterly indecent and when it takes that extreme, then extreme measures are appropriate, whether it be bigger bail-outs or capital controls. I will argue that capital controls are not an attractive solution for the world economy, that they don't solve the problem and that they encourage the worst. But that is an immediate response to the provocation of my sponsor, who said we were coming to the interesting part of the policy discussion and it is a reaction pre-emptive to a challenge no doubt from Professor Musgrave, whose judgements surely will be respected.

What I want to do is ask how to create a better world. In the end, if we have a diagnosis of the problem, we see a very active economic and by now a social problem - it's a plausible question to ask, "How to create a better world?" And that surely has two dimensions: one of them is in the individual countries, what do they have to do, and the second, is there a way of organising the international system in a fashion that also provides a better playground? Medical analogies are totally appropriate, and the very first thing surely is that the sick have to make sure that they don't get sick and the second one is to have better health care facilities, so that when people come to the hospital, they don't die there. And the third is: whatever public health initiatives are appropriate so that everything is a much healthier place in the first place.

With those analogies in mind, there is also, of course, always the question of where most of the effort is appropriate. It, surely, isn't right to say "we all have to do better", which means everybody says "well, let them do it and I don't need to". I think that 99 and 3/4 per cent of the effort has to be in individual countries and the clearer that is made, the more they will do in the direction of avoiding to be crisis-prone and in responding better when accidents happen - and, of course, there is an issue for the international community: but even there the balance between a bail-out, once one is a bad situation, and efforts to create a better environment which will lead to fewer problems is very important to emphasise, and 99 and $3 / 4$ per cent of the action has to be in creating a preventive environment, and then, as an aftermath, and as an after-thought, a little question of if then is an honest mistake, if there something does go wrong, should we just deplore that fact or should we try and do something about it?

But I think that the question goes further inevitably to ask whether the exchange rate relations among the major industrialised countries that, at first sight, have nothing to do with the default of a Russia, of a Thailand, in a deeper way do have a bearing, and if there is a bearing, whether it helps to limit the range of fluctuations of those rates, simply because there is a suspicion of, perhaps, a firm realisation that they have a bearing on the problem that they are part of the cause, and for that reason they should be abolished. 
That, of course, in itself is a proposal that has been made in advance in France with some enthusiasm - the French always like to fix things - and it now gets great sympathy from Germany's leading amateur economist. So, I will address the issue and the answer, of course, has already been given by the U.S. Secretary of the Treasury who said, "fixed exchange rates are dumb".

Let me start positioning the topic and saying: "In the individual countries, how do you assure that the crisis issue is handled better?" And I think that has two perspectives. First, to have an environment in which having a financial crisis is substantially less likely, and the second one, if even so something has happened, what is the right response? The question of how to have fewer financial crises or a smaller likelihood of a financial crisis really has to do with an institutional setting where you have far more stability - and with far more stability, far less of an incentive for large adverse speculative positions. And the cornerstone of that, looking at all the crises we have had, is to see that the exchange rate always is a very central part of it or becomes a very central part of it. I say "is or becomes", I make that distinction because in Russia, there was no exchange rate issue until everybody wanted to leave. And, when everybody wants to leave, then, what is actually a public finance problem, very quickly becomes an exchange rate problem. In other situations, the exchange rate is very much part of the problem to start with in large current account deficits and in a loss of growth, and my talk yesterday about Brazil is very much that. The exchange rate is the central part of the story - the more people believe that a large devaluation could be happening by choice of the government, or inevitably once there is one-way-traffic to get out of the country and nobody on the other side. When the possibility of a large exchange rate movement comes, and then, of course, excess profits lure in, anyone, call them speculators, call them investors, call them arbitrageurs - if it's sufficiently certain they are arbitrageurs, they aren't even speculators. So the exchange rate is there, that's what provides the extra 20,30, 40 per cent, that's what it makes it worthwhile looking at. Nobody is going to move a lot of capital for a half percentage point, unless it's a very certain proposition - and everybody will, for $20,30,40$ per cent that are quite likely.

How does one deal with the exchange rate? One answer is to have a floating exchange rate. And a market-determined floating rate always is in the right place, and if it's in the right place, then nobody can form the assumption that, soon, it's in a very different place because if that was really a credible belief, then, of course, it would be already there. So, flexible exchange rates are incredibly tempting because they are the right exchange rates, and how can they be an invitation to a significant speculative problem? I think that isn't an attractive answer, because a flexible exchange rate doesn't really exist. Every country has a central bank, and every central bank doesn't like the exchange rate that they see in the market, and shortly afterwards they will manipulate the exchange rate. And the moment they manipulate the exchange rate, we're back to exactly the same set of issues that would be there under a fixed rate. Perhaps they have a little bit less incentive to have deeply misaligned rates, but I haven't seen an exchange rate that hasn't met a central bank that didn't want to do something to it - and always in the wrong direction.

So, I rule out the distinction between pegged rates and flexible rates. I do not believe, in the countries we are talking about, a fully flexible rate is really acceptable. When the politics goes bad, the central bank will support the exchange rate, and when they support the exchange rate, they do exactly what the Thai government did or the Korean government did, no difference whatsoever, and they'll have the high interest rates, and 
we know the high interest rates aren't sustainable, and we are back entirely to the discussion we have had, whether it's a talk about Britain under fixed exchange rates, or we are talking about any other economy that had something different from a fixed rate system, but in the end, had just the same currency crisis. And Indonesia might be a good example, because for a moment they thought they had a flexible exchange rate but it really wasn't. So one has to go further in saying what to do about the exchange rate, and the right view is to abolish the exchange rate. A country that doesn't have an exchange rate can't have a currency crisis. Now, not having an exchange rate, of course has a pretty radical implication because it essentially disarms the central bank. And disarming the central bank has two problems: one, that there are people who say monetary policy is a very important tool of economic policy, and economic policy is employment creation, responding to shocks, doing something to make the economy function better. And giving up the central bank because you have now an exchange rate that is gone - that is too extreme. The right response to that, I think, is that very, very few countries in fact can exercise an independent monetary policy. It's certain that Europe can, it's certain that the U.S. can, and it's almost certain that nobody else can. They can entertain the illusion, and they can pay high interest rates as they practice that illusion and the more they do so the higher the interest rates, but the results are very substantially in doubt. It is true that like Thailand, they can lower interest rates below Singapore for all of three months, if they spend 40 billion dollars on it, but if they don't have 40 billion dollars to invest in that experience, it isn't even going to take that long. There is an illusion in Mexico that they have monetary independence, and that's why their interest rates are 36 per cent, and they pay 36 per cent for that privilege. Brazil has independent monetary policy. Their real interest rate is 40 per cent, and that's what they are paying for having a central bank.

So, independent monetary policy as the argument for having a central bank is really a stupid proposition. Wherever you have a banana republic practising its independent central bank, they're having New York plus. And the more they practise it, the bigger the plus. The notion that any country on the periphery of the world could lower its interest rates below New York because the risks there are so far less than in New York, that's adventurous thinking. I think there is one country in the world that teases its investors by saying "we can, of course, look to the day where we pay less than in New York because in the long run, we will have a better inflation performance and therefore look to currency appreciation". That is being said in Argentina but it's being said tongue-in-cheek while they enjoy their currency arrangements which get them closer to New York than any other emerging market.

So, I want to emphasise that the argument monetary policy independence, on the periphery of the world, is something that is a grave and deep illusion. Cutting your interest rates below New York is something you can do if you are much more wonderful than New York. More wonderful, in the sense of having a prospect of currency appreciation, and more wonderful in the sense that the sovereign risk is less than that of the United States of America. The two together on the periphery of the earth would be surprising. Maybe a Singapore can do it - maybe: Maybe a totally dead Japan can have low interest rates, but surely not Romania or Bulgaria, or Poland or Brazil, or Mexico, or for that purpose, Thailand or Korea.

But there is another important argument about the exchange rate and the central bank and the money - that a country's money is the very expression of its sovereignty. A money has to do with national identity, with national pride, and to give up a money is to 
give up yourself. And that is sort of a joke, because think of the typical Latin American economy. They will have had their first money some time around 1893, shortly after they were pushed off the gold standard, and they will since then have had 20 - 30 monetary reforms: everyone either taking off the zeroes, you always do that when you put the force, or having simply new names on the money. It's the peso, then it's the hard peso, then it's the gold peso, then it's the new peso, and then you run out of pesos and go to other names, right? Then you have a dollar for Hawaii because things are really bad, and then you go back to the pesos. Anyone who has studied Argentine monetary history knows that you can paper the whole wall of the Senatssaal with the various kinds of pesos they have had in the past century. So, the point is, anyone who takes pride in that, has to ask themselves whether they are really serious. If people did to the national flag what they have done to their money, they would all be in jail. The argument that it's national pride that makes you have a money is very expensive proposition. I can't accept that anymore, everybody understands that the problems of Latin America, for example, is the deep mismanagement of money. And the sooner one can get rid of the money, and the more radically one can get rid of the money, even if that is a new proposition, the sooner there is a prospect of economic stability, sustained growth, fewer social problems and more reason to have national pride.

So, how does one get rid of an exchange rate? I think there are three ways to do it: one doesn't work, one works, and one works very well. Not working is to say, "And now we have a fixed exchange rate": That works until further notice. And monetary history in every country is replete with the proud minister stabilising, announcing the fixed exchange rate and everybody is saying, "That's what they always say at this time". And it lasts for a while, and it's typically in the context of a stabilisation programme. It typically works in reducing the inflation, it typically means that an overvaluation is built up, and in time that exchange rate comes under question, as it does, the interest rates will start increasing, and then it's a question of time.

So, fixed exchange rates of the garden variety of administer announcing that that's our policy is a proposition that instils very, very little credibility, that costs significantly in the interest rates for the very reason that it has failed a thousand times, and for that reason is both expensive and ineffective. I don't think today that anyone who says "we have a fixed rate" would get anyone else to make a bet on that lasting more than five years, at odds different from ten to one.

The far better way, of course, is to have deep institutional change that makes it virtually impossible to change the exchange rate. That is hard to accomplish because on the periphery of the earth, institutions don't really exist. A country like Brazil has many constitutions, and most of the time they are spending, amending the last one. And when it gets too big, then they make a new one, and then they'll amend that for the next ten years. But there are constitutions and then there are fundamental laws, and they all have to do with how you can't repudiate your debt and how the government can't steal from the people and then it's done under some other pretext.

So, one has to go very, very far in creating an institutional environment to actually make sure that the exchange rate is beyond the reach of politicians, at least with reasonable ease and that the central bank is taken out of the process of managing the exchange rate with great assurance. That is technically impossible. But, there are two facilitating circumstances. One is if a country has suffered a deep disillusion about its ability to manage its own money, surely that is the case in a hyper-inflation, surely that is the case 
when most citizens have left the national money and hold deutschmarks or dollars, whatever they are closest to, and then de facto, the public supports a hard money. That's what they themselves have chosen; that's what they themselves most easily accept the central bank should be doing.

That disillusion is the best institutional support for hard money. One sees that in Germany in a continuous support of an anti-inflation and a relatively independent central bank. One sees it in Germany in the strong reaction of the public to the proposition of Lafontaine that the central bank should be managed by him, and not the independent council. That is the very, very best thing you can do - a lot better than what you write on paper. But the second part, of course, in any functioning democracy, is to put very substantial hurdles against the discretionary change in exchange rates. Substantial hurdles are great majorities in parliament with which an exchange rate change can be done, but it takes that majority. And it takes a discussion, which in itself, of course, is something that is virtually impossible in the context of exchange rates. Argentina has done just that, in the context of a hyper-inflation, a total disillusion. In the early nineties, everybody was dollarised already, and the stabilisation proposal is, "This time, we don't do what we always say. Promise we are going to be good, fix the exchange rate and not do anything else. Instead, get rid of the central bank, put in the constitution that the exchange rate can only be changed with a two-thirds majority of parliament, and put the central bank on a hard currency board arrangement", meaning that money supply changes respond one-for-one to foreign exchange purchases, with absolutely no discretion or intervention. And that means monetary policy is gone: when foreign exchange comes in, the central bank buys it at the fixed rate and issues pesos, and when foreign exchange leaves, then the central bank is financing it by contracting the supply of pesos as they sell dollars in support of the exchange rate. And the central bank becomes a very, very dull place. And it's essential that it be a dull place. A dull central bank is the best central bank. And that central bank the same day will have to abolish its wonderful pension plans; it will have to abolish its cheap mortgages for employees and that's why they are so big; it will have to stop supporting the government's budget because they can't create money anymore at pleasure to finance the deficit - a totally new world.

A currency board arrangement, a fixed exchange rate and a central bank that has no discretionary power over the money supply has bank supervision, perhaps, as a responsibility but nothing else, is a very, very good system. That used to be the British colonial arrangement, so that in the colonies people could put their local heroes on the money, but not play with it, and it is becoming fashionable at least in discussion, but also in one spectacularly successful case, and that is Argentina. It's used in other instances, but $I$ think the Argentine experience is the one that deserves most attention because, one, it has lasted, and two, it has been extremely successful as a cornerstone of reform in an economy, and three, it has produced an average growth rate of six per cent. And, in Argentina, that's a first in this century. So, the notion that a currency board is the first step to crucifixion is really totally incorrect. On the contrary, it may well be a very decisive and very pervasive step, to creating people's expectations of how their economic life functions. More so, the more their life has been degraded by persistent monetary debasement that has been the main part of macroeconomic experience.

Technically, a currency board is easy at the end of a hyper-inflation because the whole country, already, is on the dollar, everybody has bought the dollars, the all have them in their pocket, and the only thing that is left is the central bank trying to squeeze some 
more of the local money on to unwilling customers. Then, it is truly easy and, of course, the public will support it. It is also attractive because the moment it is done, inflation is over from one day to the next because one step allies as the key price that everybody watches. A currency board is much, much harder in a country that isn't in an obvious crisis, that therefore would wish to muddle on with minor measures rather than with extreme medicine. It is much harder in a country that isn't fully dollarised or fully on the deutschmark, and it is much harder in country that still believes that the central bank can do a little bit either for the government's budget finance through an inflation tax, or it can do a little bit even to create employment: a much more ambitious task for a central bank that takes a higher degree of money illusion. But I make that distinction because it is often said that a currency board isn't a practical proposition. But what is a practical proposition, of course, has to be judged against the alternative, and to have a currency crisis every four years and a dead default every five years, and no per-capita growth for twenty years does not strike me as a very practical way of running an economy. So, against that, a hard money move, even if it takes intellectual discipline, decisiveness, commitment of political capital, seems a very, very worthwhile investment.

There is also an argument that a currency board requires that the central bank be able to back the money supply with foreign exchange, and if they don't have the foreign exchange, then they can't even start. I think that is most of the time not an active issue because countries on the verge of a currency crisis or beyond it, typically have relatively little domestic money left and with the devaluation that inevitably will have happened, the exchange reserves left easily back the remaining money supply. But where that isn't true, surely the extra three privatisations will supply the foreign exchange to do it, or even the borrowing used rather to create a currency board than to have one more month of a party. So I dismiss the argument the reserves aren't there, therefore we cannot do it because the same people who say it are about to waste the privatisation revenues or the access to the capital market.

I want to come to a key question of whether there is something better than a currency board. And the something better is of course to give up altogether the national money, and directly use foreign exchange.

I think that has two dimensions. One is that if the country isn't substantially equipped with foreign exchange in everybody's pocket already, then it's more expensive to say, "Go on the dollar because everybody needs dollars". It isn't just that the central bank needs some money, and perhaps enough money to back the money supply. I think that is a technical issue that is important.

The second one is: what money to choose? That is an obvious question if you live next door to Germany or Europe; with the euro coming it's an obvious proposition in Latin America, it is less obvious anywhere else. Except, one has to look a Hong Kong. Hong Kong isn't near anyone else other that China and is doing very, very well on the dollar. The Hong Kong Currency Board has left Hong Kong standing far, far better than any of the other economies in Asia except in China. So I think that is a secondary issue with whom to do it if one is lost somewhere a little bit distant from either Europe or the U.S. It is really a secondary issue as to what currency to fix to. The trade pattern is one concern, international capital markets are another, and is it the euro or the dollar? That is not the key question although it's well worth technical consideration. 
Why is it little bit better to totally give up the national heroes and use a good money in existence? The argument of course is that a newly created currency board creates with it the suspicion that it will not last. When the national money is gone it is very hard to bring it back to life. It just is not there anymore, but a currency board has national money outstanding. There is banking system that may not be operating totally in foreign exchange, and therefore the flirtation with the devaluation will always be there as a possibility. We see that in Argentina, where there is a moderate premium of peso interest rates over dollar interest rates. It's moderate but it is still there and it reflects the remote possibility that there could be a devaluation. But that premium at the outset in Argentina was much more significant, because here was a country that had never stuck to anything and why should you believe that they will stick to this one. So there is certainly a transition period which takes away some of the sheer stabilisation that one hopes from the medium, and that of course would be eased if one went all the way to the dollar and did not have that intermediary step.

There is also the little bit of suspicion that is nourished by the Polish experience in 1927. Poland had chosen to go to hard money. They had created a currency board, and they had created an independent central bank that was functioning totally on the currency board principle, but they had left the creation of coins to the treasury. In its despair the treasury created a mini hyperinflation by minting coins; but under the sheer weight of the coins that also stopped. But bear in mind that if public finance is an issue then even who gets to make the coins, and are they part or not of the currency board, is a serious issue, and there will always be the temptation to create some local dollars or some local quarters, and that, even that, needs attention more so the harder is public finance.

So for me the decisive question then is, somewhere between currency board and being outright on foreign exchange, with important technical questions of under a currency board can small change be local and can that be limited seignorage and is there a little bit of room in a pre-set, and responsible way not to give the seignorage, the revenue for money creation at that level, away. Those are interesting and important questions. They are worth a quarter percent of GDP, but that is a decisive part of revenue. To some extent one can do that, just as the stabilisation of the German hyperinflation, there was a one-time, limited money issue. But it was one time and it was limited and therefore it was compatible with stabilisation. I think the same kind of possibility exists in a transition to a currency board or even in a transition to being all the way on the dollar.

Some countries in the Caribbean are all the way on the dollar except for small change, so that anything less than a dollar bill they can do themselves and put the heroes on. Yes, there is the risk of the Polish maybe hyperinflation of the little coins, but you also can exaggerate your inflation fears. So, I think there is territory to operate between being all the way on the dollar and a currency board with interesting issues where a political compromise can be made without great responsibility. But the decisive issue is to disarm totally the central bank, to have it therefore completely removed from public finance, put on automatic pilot and in that way take away the currency issue all together. And that that should be substantially institutionalised, whatever is the hardest legal arrangement in the country, and that the public should substantially come to the support of that in understanding that is the best chance to a rising per-capita GDP. Which means someone has to give a speech that says we have forever ruined people's life by the operation of the national central bank. Everybody will nod when that speech is finally given and that's the first step to doing things right. 
I want to take Brazil as an example of how to get out of a problem. Brazil's real interest rate is 40 per cent, and it's 40 per cent because nobody believes that the exchange rate will stay. And the government says "it will stay" - and people say "well, I'm not surprised you should say that. Governments always say that at this stage of the game. But I don't believe it, and therefore, to lend in local currency, I need to be paid 40 per cent". 40 per cent, of course, is a lot, because even a likely depreciation in Brazil would have to be a Russian problem, but everybody has seen Asia and it's always a hundred per cent, so get yourself enough. Brazil's real exchange rate is a problem - in a recession, it's a bigger problem - the exchange rate will be looked at as the prime suspect in the months and perhaps the year to come. And nothing would persuade people that the government's commitment to depreciate the exchange rate at seven per cent per year steadily and no faster, even though agreed with the IMF, in the end is actually going to happen. And because nobody believes that with great assurance, the interest rates will not go down, and if the interest rates do not go down, then it is not going to be true because in the end, it's unviable.

How do you break out of that? Well, the president could give another speech that he is totally determined. His minister could give the six-hundredth speech. But everybody knows: anything that can't work isn't going to work. Why not do the extreme? Well, the extreme - people say, "no, we don't want to devalue". But that isn't the extreme. Devaluing, of course, would seem to solve the competitiveness problem, might well even solve it, but of course will create a balance sheet crisis because there are huge liabilities in dollars, will surely raise an inflation issue, and will surely raise the question of what comes next with the exchange rate because here it has gone once, surely that isn't the end of the story. So, devaluation, yes that is a radical answer, but it isn't really a lasting and final solution. It just means that the next five years will also be macroeconomics rather than getting out of that and doing something else.

The radical answer in Brazil is to just have a currency board on the U.S. dollar. It's radical because it is totally unspeakable that a large, inward-looking sovereign country that has taken pride in its own mismanagement for the past 50 years, should just say "we have screwed up forever, and we are now going to give the people liberation from our central bank". That's hard. But, it's so hard because everybody says, "You know, what's so bad? Inflation has stopped". They aren't saying, "We have had zero percapita growth for twenty years, we have the worst income distribution than any other country in the world." That is not the main domestic theme. The government has been extremely able in the past few years to keep the music going by borrowing and spending. Of course, the borrowing is over and the privatisations have been spent, and now comes the reality check. That reality check is going to be far, far more effective by having the fiscal adjustment mostly done by a gain in confidence from a hard currency arrangement, rather than trying with increased taxes to run off their budget that doesn't get better because of recession, recession that doesn't get better because the interest rates are so high. I think that vicious cycle has to be cut. I think a currency board is an answer. Introduce it. It will not immediately command full credibility. It may well be that Brazil pays ten percentage points more than New York, but right now they are paying 35 per cent more than New York.

Ten per cent would be a very, very modern premium, but even that isn't clear because Argentina next door has given the example, has shown the success, and investors might well believe that this is the decisive regime change that everybody has been waiting for. They might well get extremely excited with what just has happened, and Brazil might 
never have any hardship at all. And, yes, that's possible. But, I think that may be too optimistic. Maybe there is some scepticism to start with, but surely the interest rate problem would be very substantially solved. With that, the growth problem would be substantially solved. With that, the budget problem would be substantially solved, and if they are solved, then Brazil could suddenly start being a normal country.

So, I believe, currency board in Brazil, while it's a huge change, it's exactly the huge change that is required, so that macroeconomics is not the dominant story of everyday life as it has been in the past twenty years, with hyper-inflation, with price-freezes, with maxi-collapses, with wiping-out of debts, and all the adventures that have been practised. It's an extreme measure. It's something that in 1970, nobody would ever have advocated, but after another twenty years of monetary experiments, it suddenly becomes an extreme, plausible cure.

The difference of currency board versus all the way on the dollar, I think you want something that can work fast and easily. In Brazil, the reserves and the IMF package are widely enough to back the local money supply. There is no issue here.

There is a second question in that context, of course, whether fiscal policy has to be part of the support for a currency board. And, I think, the more important question, what has to be happening in the macroeconomic structure of a country to make a currency board viable. I think the fiscal discussion is exaggerated, much as the discussion about European monetary union needing fiscal co-ordination and a Waigel pact; they have nothing whatsoever to do with each other. A country that has credit standing, can borrow in the rest of the world, and if they do that, that's perfectly alright, and that doesn't threaten inflation or the central bank. And if they can't borrow abroad, then they can't borrow abroad. As long as it's clear that the central bank isn't printing the money, then the deficits will go away. Deficits that cannot be financed typically don't exist. They exist in Russia and I call wage arrears, and that, of course, isn't a good arrangement, but anywhere else, it's an unnecessary discussion. In the Brazilian context, to stay with the example, most of the deficit is the counterpart of the huge real interest rates. So, if they go away, then the fiscal problem substantially has gone away and comes down to a size that is easily financed in the world capital market, or in the domestic capital market, with extra support from more privatisations. It's just a non-issue. So, I want to emphasise how solving the interest rate problem in this particular case really solves the fiscal problem. And we don't have to have a separate discussion of it.

In other countries, the currency board would also have been a good idea. Surely in Russia, if the IMF in its first programme as opposed to the second - they never got the money - had insisted on a currency board and had used the IMF money as support for a currency board rather than to pay off foreign loans, Russia would not be today where it is. The IMF didn't have the courage to do it, they said, "It's a big step, it's the last bullet". The argument, "It's the last bullet", is really a very, very bad argument if the war has long been lost before you get to use it. At some point, you have to have a bit of courage and understand that unless you do the regime change, you don't get a chance anymore. And in Russia, that was clearly the case.

I think it's a little bit more difficult to make the argument that in Indonesia, the IMF should have supported a currency board. Indonesia got very, very excited in the midst of a tight IMF programme, with the idea that, if they had a currency board, then all their problems would be solved, because interest rates would be immediately down, and the 
currency would be hard and the devaluation would never have happened because they could have it at a very, very high exchange rate. And all the world's money would come, and maybe they would be doing better than even before. And that argument was used to get from the IMF a few billion dollars for the currency board, and the IMF said, "No way", because the whole ploy is for Suharto's children to steal the IMF money. And I think that is substantially true. So, I make a big distinction between the Russian case, where it was decisive to bring a change in the economic regime, and for everybody to see that, and where the economy was totally dollarised, so that a currency board really had in people's pockets already its equivalent. And Indonesia, where, I think, it was a ploy to steal money, and I return to Indonesia in that context.

Brazil is for me the favourite example because I look at an economy that has a terrible track record from its own macroeconomics. I look at a neighbour that had the same experience, went for the cure and has done spectacularly with it. I look at an on-going problem in Brazil, even if they don't have an immediate collapse or a collapse soon, when macroeconomics will continue to be the difficult discussion. But I have to address the question of how a country with an overvalued currency, as I claim, could possibly now proceed to have a currency board at that overvalued currency. Isn't that a really terrible way of going about it?

Of course, one argument is, have the famous last devaluation and then do it. And that, of course, means that even as you create a new world, you kick people in the face just once more for good memory. It, of course, would help to give you momentary gain on competitiveness, and in that way, make the currency board more credible, but it also would put in place inflationary forces which then, very soon, would become a question for the new currency board. I think it draws attention to an essential complement for a currency board - and that is a very competitive economy, where you have substantial ability of wages and prices to go down if that is necessary. So I believe it has a need for doing more than just fix the exchange rate. There is a need for the government to get out of wage policy, and for the government to accept that wages and prices may actually have to fall.

Is that possible? The answer is, "Yes": in Argentina it's happening every day. In Argentina, in large firms, you have had major wage cuts: 10, 15, 20 per cent across the board for all. In Argentina, you do have deflation even in a situation of seven per cent growth. It's totally wrong to believe that in countries that have large monetary instability, there is no flexibility on the downside once the decisive regime change has occurred. But if you have pervasive government arrangements in the wage area, and if the government does not complement in the wage area or allow a market to do it, a currency board, then, of course, there is a conflict set up right from the beginning, that is inauspicious. So, a very competitive economy is the natural counterpart of a hard money so that the price system can still do its work.

I will now come next to the second pillar of a better, and a more preventive system and that is a much easier one, and that is a good banking system. A good banking system substantially means bank regulation, bank supervision, bank capitalisation. And everybody knows what a bad balance sheet is. A bad balance sheet has lots of real estate, lots of equity, lots of foreign exchange, and lots of loans to the owners of the bank, their close relatives and the others who already have emigrated. 
So, I don't want to say more about bad banks, but it rises essentially in the context of a hard money to say, "We can't afford a hard money because we have bad banks". That is the wrong way of arguing. If you have bad banks then you very urgently want to clean up your banks because bad banks go only one way: they get worse. In the end every bank is a fiscal problem. When you have bad banks it is in a political environment where it is totally understood that the government is going to bail them out in the end and that's why they are so bad and that's why the get worse. So cleaning up the banks is an essential counterpart of any attempt to have a well functioning economy. It is a counterpart of any attempt to have a dull, uninteresting macroeconomy. And there is no excuse to do it slowly because it is very expensive to postpone the cleanup. There is no technical issue in doing the cleanup. It's mostly to decide to start to grow up and stop the mess.

If you have a hard money and if you have clean banks then you don't have macroeconomics as a problem anymore. Yes, you have slowdowns in the economy and yes you have booms and the key macro problem, the government, has been taken out of it. That's very important to understand that in the economies we are talking about, the problem is the government. The government is not the solution. Hyperinflations are made by governments, debt defaults are made by governments, exchange rates crises are made by governments. And if they don't know how to do it well, and the assumption is: no they do not know how to do it well, then take them out of the business. When that happens, spectacular results are the case. Hong Kong with its hard money even in the midst of a regional dramatic crisis, is there; their banks have not defaulted, yes, they have a recession, I'd have a recession too if my customers all disappeared. But, I think I wouldn't default - and that is the case of Hong Kong and just in the same way Argentina - and hope for an early test. In Argentina that was 1995, and that was a recession year.

And now Brazil comes and they say, "This time we won't even have a recession. Our banks are even better, and we are even more competitive, and we don't really expect that we will have negative numbers when it happens". I think when a country moves from hyperinflation to that level of confidence in seven years and looks forward and says, "We can deal with problems", it's a fantastic transformation. And it's an indictment of the arrangement they had before, and it's a support for very, very substantial change in regime, which in the end isn't costly, painful or expensive, but rather the best thing that someone can do to oneself.

That of course is very important to highlight because the assumption is that when you do a currency board you are doing a cutting off your leg. You are doing something terrible to yourself and now it is agony and austerity. In fact it is the first day of a much, much better life, which will give you far better access to external credit, far lower interest rates and take the government out of business.

I am disappointed that the IMF has not had the courage to be far, far more aggressive on the agenda of hard money and clean banks. It is totally obvious to anyone in the IMF, that the only problem is the governments. But, of course, since they only talk to those governments it is very hard to tell them, "Fritz you are the problem". But they don't have to say "Fritz you are the problem, or Hilda", what they ought to do is flood the world with publications that show in large cross-sections that governments always are the problem. Nobody has any doubt in any class in monetary economics that inflation doesn't come from heaven; that it is made by central banks. There is no question. And 
why is that not allowed to enter the discussion in the same way that exchange rate crises, debt crises are made by a government, are essentially the political fall-out of bad economic policy.

So the IMF, if it wants any claim to going in right direction, has to be far more aggressive in disarming countries and taking governments out of the business. In Argentina, the IMF has no claim whatsoever for having assisted in a currency board; the IMF was sceptical. In Russia the IMF had no support for a currency board and that is why it did not happen. And now we have a different Russia.

Why is that so? I think that is a very, very important question in political economy. It is perhaps too cheap to say that they would lose their customers, but it is not totally remote as a proposition.

Then we come from here to an entirely separate question. Once you are in a crisis, and it has happened and all the wisdom you may have heard before and discarded, and that has become irrelevant, how should you react?

There is one idea: capital controls. Everybody wants their money out, the IMF is screaming that you raise your interest rate, George Soros is banging on you saying, "I want to bill you", and your opposition is getting into the streets and the exchange rate is falling rapidly. The decisive step to take, and to have the courage to take, is capital controls. That is instinctive. If it moves, fix it; if they want their money back that is unfair because we can't pay. The fact that we borrowed it overnight and they thought they could get it back is irrelevant now because it is so obvious that it is very costly. It's immensely tempting to have capital control because the place would become very, very quiet the moment afterwards and the sheer relief of that quiet is the great promise. To let the exchange rate collapse, that isn't an issue of quiet, because the more it collapses it is not true that the more competitive the currency and the more people will come in because it can only go up. It is really that if more public order breaks down the opposition gets a voice, the central banks starts printing, the defaults are left and right, the bankruptcies of all the people who lost on the dollar ruin employment; it's the opening to a disaster.

So, why not just be realistic and at the slightest sign of a crisis slap on capital controls and avoid altogether the meltdown. What is wrong with that? I think there is a big distinction between capital controls as part of the system in some form, and capital controls as means of spontaneous resort to the loss of control.

But I think capital controls are the wrong answer. If a country has an extraordinary withdrawal of short-term credit and they made the mistake of having short-term credit positions, then they should have a debt restructuring. Then they should say, "We are now going to default on our debt and we are very, very sorry and what you thought was an overnight loan actually isn't an overnight loan it is a long-term stabilisation loan. That makes an extraordinary important distinction between direct investment, which should be favoured at all times, and you should create a history of always treating direct investment extremely well, and short-term debt, which if thing go bad may turn out to be long-term debt. If that were done, then of course the foreign exchange problem would be solved. 
I make that distinction between capital controls and debt re-negotiation or debt consolidation or debt restructuring - make it sound as favourable as you can - that solves the foreign exchange market problem. If it is done in that way, and 1982 is an example, then the one-way pressure in the foreign exchange market is gone overnight. It is not the end of the problem because a country may have to finance a current account deficit and therefore there is still adjustment to be done. There may even be a devaluation to be done, or the choice is not to do one, but at least it is not the free-for-all collapse. Governments are extremely reluctant to address the debt issue because on the other side the argument is, "Never, never even dream if it". Official institutions support exactly that argument because they are terrified that Citibank should scream at them, which Citibank would do. But surely there is absolutely no reason in a Russia to have a wild collapse of the price system, the exchange rate and everything simply because people are unwilling to tell short-term foreign investors, "Fritz you have got to stay for a while".

The IMF should have in its first stabilisation programme, along with a currency board or to lengthen Russia's debt, persuaded the investors to do just that. Exactly what they are trying to do now in Brazil, and had they done it the Russian problem would not have existed. Then, in time, the effort on the budget, which of course is totally essential and indispensable might well have happened; something that now is beyond belief. The debts that the IMF did not want to restructure now are simply defaulted with no prospect of getting paid in my lifetime.

So, I make a distinction between capital controls, which is a switching off the radio, and a very structured debt re-negotiation which can be substantially differentiated, which can be agreeable, which banks when they know the choice is not to have a word in how it's done or actually get a little bit of discussion of course is something that can happen, and it can even happen on a weekend.

I think the IMF is surely responsible in Russia for the failure to have that and for the use of the stabilisation money for half the people to get out and the other half to be caught and that produced the currency collapse. The IMF argument is that if they had had a debt restructuring that would not have avoided a currency collapse. Well, I don't know that for sure, what I do know is that we have had both. So, it is a risk well worth taking.

I've talked about what the individual country should do and that leaves me with the question of having a better system. The very first question is whether exchange rate movements among major industrialised countries are a very systematic part of creating the crisis environment; that argument has been brought specifically in relation to the U.S. dollar.

The U.S. dollar strengthened forever. Thailand was on the U.S. dollar. And because they pegged on the US dollar, they lost competitiveness day after day after day as the dollar was rising. That loss of competitiveness is what triggered the crisis. There is no question a germ of truth to that. It has a lot more to do with Thailand being on the dollar and allowing domestic wage inflation significantly above that in the United States, having a substantial fiscal expansion even as they experienced real appreciation, having a happy boom going on and doing all of that even as their export prices were falling. Yes, the dollar had a lot to do with it. But should we go from there to say it is totally essential that we fix the dollar-yen exchange rate so that a Thailand can then fix to the dollar and 
not have a problem? I think that that reaches very far into the performance of the world economy and the costs of fixing exchange rates amongst major blocs of course are far, far more significant than what happened to Thailand, which mostly has to do with its mismanaged finance, and not with the dollar.

The real appreciation that happened in Thailand is of the order of $5 \%$. If you stretch it $7 \%$, and nobody dies from a $7 \%$ real appreciation. I mean that is a dose that you can give to children and they are alright. So, I dismiss both the dollar as the central player in the Thai story, I have argued it was their cutting the interest rate well below Singapore that did it, and I surely dismiss the notion that we need international monetary coordination to make the periphery a safer place. The periphery has to work very, very hard on its own institutions so that it can get good economic performance in a world that is per force both volatile and suspect of the periphery.

If that is better understood then the periphery will do well and in the meantime we can enjoy the volatility of major exchange rates. I think there is no prospect on earth that the U.S. dollar and the euro will be fixed, or will have narrow target zones. It's well understood that that can only function by a culminated monetary policy. It is totally certain that the U.S. Congress and our Treasury and our Federal Reserve is totally unwilling to fix its destiny to Mr. Lafontaine. And it's also clear that the European Central Bank is unwilling to fix its destiny to a Federal Reserve that may not forever be governed by Greenspan. I think that varies that topic entirely.

Well I think that shifts your discussion more to two topics. One is the IMF, and should we re-arm the IMF and make them more able to conduct big battles; the large shootouts with the hedge funds. And if we give them nuclear weapons and the other guys only have machine guns, then the good guys will win.

The second question, whether we shouldn't have, as a more systematic part of world finance, some form of nice capital controls, and the emphasis on nice, user-friendly, sweet. Let me address those two issues to complete my discussion.

The IMF question I think is deeply misguided. The worst possible world is one where we have bailout without regulation, supervision and conditionality. A good world is where we have regulation, supervision, conditionality, and a lender of last resort.

The IMF is unable, both from its demonstrated history, but also from the way it is governed by member countries, to effectively regulate, to supervise and to have conditionality. Take as an example Brazil. It has flaunted any advice from the IMF for the last eight years. The IMF has actively assisted them in the past year, to have another year of bad economic management. And it was ready with a big package to allow the president to get re-elected, and now is settling for a minimal programme which most definitely is not going to solve Brazil's problem, even if it allows it to live with little growth for the next three or four years. So re-arming the IMF I think is a very frivolous idea. It promises to get us more and more the belief that wherever you see high interest rates, make the loans, because someone will come and bail you out in time.

Is the bail-out happening because governments want the international community all at large, and at arms length to bail out their banks rather than have they themselves the costs visibly in their budgets? I think that has a lot to do with it. Japan's enthusiasm for bail-outs in Asia have a lot to do with the Japanese banks that have made the loans and 
surely the same is true when the U.S. is very enthusiastic about bailing out Brazil or Mexico.

But we have to understand that that is to share internationally the costs rather than having in the budget, and to share the costs rather than being insistent that very important changes happen in economic management. It surely is the wrong system for the world economy and if governments like it that is one reason to be suspicious.

So I have no sympathy for stocking up the IMF to give them money, so that wherever the world's problems happen they are there to respond. I once wrote - and Stan Fischer was very generous to me, took great stress from it - that the IMF now functions on the system 1-800-BAILOUT. To be responsible I called that number and it is actually the West Texas Bail-Bond Association. So I thought maybe that was the wrong number so I tried "1-800 IMF-STAN" and that's a French lingerie shop. So I don't know what the number is but $I$ have written this and a former student in Brazil said, "I really like your idea because you could have 1-800BAILOUT and then you get prompted: one for sovereign defaults, two for commercial debt, three to talk to our specialists. We have to understand that the system has allowed itself to be pushed to a position that is deeply counterproductive, where the effort at reform is small because the lending countries are too eager to put their money on the table to give you another year of peace.

The more important question is the one of some form of capital controls as part of the system. The argument is: there is too much liquidity around and there is too much short notice demand for money, and people suddenly want to leave and an economy cannot leave. That is a problem if you don't like bailouts, then you have administratively to minimise that situation. I have argued in my lecture two days ago that the way to address that problem is a national balance sheet that is not so liquid, and that happens automatically in a world where the banking system is well supervised and that that is the effective way to address that issue.

But it is important to take seriously the proposition of Jim Tobin of years ago that there is excess trading; a proposition that actually goes back to Keynes who said that the great problem of America, is that people are traders and not investors and that therefore the place is a casino. The way to do it is to have transactions tax and that idea of Keynes, Tobin took very seriously in the sixties, to say: "Put some sand in the wheels, something that slows down the traffic". Transactions tax a very, very small transactions tax which makes it unattractive to have daytime roundtrips but does not interfere with mediumterm investment. If it is a small tax, then on a daytime roundtrip it takes away most of the returns you could expect from a day trip, but advertised on a year it is insignificant and on five years you don't even pay attention to it.

The Tobin Tax is an extremely attractive proposition in a world where trading predominates, and capital gains mentality predominates, and a belief in liquidity predominates, which when exercised turns out not to be right, and creates market problems. It is speed limits. Speed limits are totally wonderful and create a safer environment. They create a safer environment because they take the few people who are risk to everybody else and do not internalise it by limiting the damage they can do. A Tobin Tax is like gun control. Gun control is wonderful because if the other guys don't have guns either nor do I need them; I safely can be a long-term investor. 
So a have great, great sympathy for a Tobin Tax but I think it is utterly irrelevant in the context of currency crises, because that very, very small Tobin Tax is utterly uninteresting when I look at a $30 \%$ devaluation within the next half year. Then, I want to get my money out. It slows down the overnight traffic it does not keep money in a place where it shouldn't be. So, any belief that a Tobin Tax fits into the discussion of currency crisis, of Asia - a Tobin Tax works when people say, "You know the next few days are not really good and I am leaving for a moment before quickly coming back". Those people would be kept in by a Tobin tax. But anyone who believes that, "This ship is going to sink and $I$ am leaving, and sure $I$ might come back but only after a large correction in asset prices", that isn't stopped. So, I think it is a disservice to Tobin to bring him into this discussion as a solution. It's a way to try to make a very dirty argument look respectable, it has nothing to do with currency crises. It is a wonderful proposition to make the New York Stock Market look two days ahead rather than just to the afternoon and the next morning.

A more dramatic proposal is that you should slow down the money on the way in. Not on the way out, but don't let it come in the first place or control the terms on which it arrives. If that is done, Chilean style, then of course it is less liquid, and if it is less liquid then you are back to more nearly slow motion crisis, and if you are in slow motion crisis then of course all the room is there to make the corrective movements rather than to have a meltdown.

The only problem with the citation of the Chilean experience is that the Chileans are very vigorous to say, "That isn't how it works and it really hasn't worked". The experience with what is told as the Chilean story of nice taxes that slowed down in Chile the inflow of capital, and allowed them to have higher real interest rates than they had before, was mostly an administrative interference that mostly worked because the Chileans are very, very sweet people, and Chile is a village.

Anyone who believes that in Indonesia Suharto's family would have been slowed down for an epsilon of a second by the presence of Chilean style controls - well it's a contradiction in terms - Indonesia is not Chile. In Thailand where corruption stank to heaven, surely nobody would have paid attention to the central bank saying, "You must not do this". They would have said, "How much?" So the notion that in Asia or indeed in Latin America outside Chile, capital controls have any effectiveness is just a joke.

On the way in it's a joke and on the way out it would surely be the big occasion for corruption. Who doubts that the last billion in the central bank in Indonesia would have belonged to Suharto's family? They would have got it and then the currency collapse would have happened. We have instances of that that are totally obvious including Thailand, where for a brief moment the currency appreciated very, very substantially and then there was a two billion dollar transaction and then the currency collapse began. Guess how that happened.

So, I am deeply suspicious of capital controls as a way of running the system and I draw attention to the importance of free capital movements in getting an effective allocation of resources. All the arguments that are appropriate in trade theory, that tariffs, quotas and the like distort the efficient allocation of capital and labour in the economy are as appropriate for capital flows; there is absolutely no distinction. But I would add an important dimension for capital flows. To have an integrated capital market along with the world economy gives you corporate governance, which is a very, very important 
reason for a well functioning economy. If you have capital controls, then you are essentially switching that off and you're putting the government in place of what otherwise would have been a market economy. You have to look at the experience with decades of relatively free capital flows and count their benefits, and not go overboard when there is a financial crisis that mostly has to do with bad supervision and bad regulation, a bad environment rather than with capital flows per se.

I'd look, and I conclude with that, at the Asian crisis as a wonderful opportunity to create better institutions and everything that we have seen in those events points at that as the lesson, and I'm shocked at the sympathy for capital flows in my profession, from people who don't know the answer and people who should know better. I am shocked by the tendency of the IMF, not to discard that as a possibility, simply because they are unwilling to assert that it was sleazy governments and bad balance sheets that are the reason, including the IMF's acknowledgement of it for years before. So I think one has to make a hard stand. A crisis offers the temptation to jump at the wrong answers really fast and it is also a temptation to assert what is right, what's true and what's good and to try and force that on the system.

Thank you very much! 


\section{CESifo Working Paper Series}

(for full list see www.cesifo.de)

860 Haizhou Huang, Dalia Marin, and Chenggang Xu, Financial Crisis, Economic Recovery and Banking Development in Former Soviet Union Economies, February 2003

861 Pedro Cardoso and Bernard M.S. van Praag, How Sustainable Are Old-age Pensions in a Shrinking Population with Endogenous Labour Supply?, February 2003

862 Volker Meier, Efficient Transfer of Aging Provisions in Private Health Insurance, February 2003

863 Edward Castronova, Theory of the Avatar, February 2003

864 Robert S. Chirinko, Hans van Ees, Harry Garretsen, and Elmer Sterken, Investor Protections and Concentrated Ownership: Assessing Corporate Control Mechanisms in the Netherlands, February 2003

865 Bernard M.S. van Praag and Pedro Cardoso, The Mix Between Pay-as-you-go and Funded Pensions and what Demography has to do with it, February 2003

866 Ernst Fehr, Urs Fischbacher, Bernhard von Rosenbladt, Jürgen Schupp, and Gert G. Wagner, A Nation-Wide Laboratory. Examining Trust and Trustworthiness by Integrating Behavioral Experiments into Representative Survey, February 2003

867 Frank Heinemann, The Inflationary Impact of Wage Indexation, February 2003

868 Eytan Sheshinski, Bounded Rationality and Socially Optimal Limits on Choice in a Self-Selection Model, February 2003

869 M. Hashem Pesaran, Estimation and Inference in Large Heterogenous Panels with Cross Section Dependence, February 2003

870 Luis H. R. Alvarez and Erkki Koskela, On the Tree-Cutting Problem under Interest Rate and Forest Value Uncertainty, February 2003

871 Norbert Berthold and Rainer Fehn, Unemployment in Germany: Reasons and Remedies, February 2003

872 Clemens Fuest, Bernd Huber, and Philipp Tilleßen, Tax Policy and Entrepreneurship in the Presence of Asymmetric Information in Capital Markets, February 2003

873 Eytan Sheshinski, Optimum and Risk-Class Pricing of Annuities, February 2003 
874 Willi Leibfritz, Paul O'Brien and Jean-Christophe Dumont, Effects of Immigration on Labour Markets and Government Budgets - An Overview, February 2003

875 M. Hashem Pesaran and Allan Timmermann, How Costly is it to Ignore Breaks when Forecasting the Direction of a Time Series?, February 2003

876 Thorvaldur Gylfason and Gylfi Zoega, Education, Social Equality and Economic Growth: A View of the Landscape, February 2003

877 Robin Boadway and Jean-François Tremblay, Public Economics and Startup Entrepreneurs, February 2003

878 Erkki Koskela and Roope Uusitalo, The Un-Intended Convergence: How the Finnish Unemployment Reached the European Level, February 2003

879 Robert Fenge and Volker Meier, Pensions and Fertility Incentives, February 2003

880 Eytan Sheshinski, Note on Income Taxation and Occupational Choice, February 2003

881 A B Atkinson, Income Inequality in OECD Countries: Data and Explanations, February 2003

882 Thomas Gehrig and Rune Stenbacka, Venture Cycles: Theory and Evidence, February 2003

883 Ralf Becker and Thomas Hellmann, The Genesis of Venture Capital - Lessons from the German Experience, March 2003

884 Eytan Sheshinski, Note on the Optimum Pricing of Annuities, March 2003

885 Paul De Grauwe and Magdalena Polan, Globalisation and Social Spending, March 2003

886 F. van der Ploeg, Do Social Policies Harm Employment and Growth?, March 2003

887 Mirjam van Praag, Initial Capital Constraints Hinder Entrepreneurial Venture Performance: An empirical analysis, March 2003

888 Bernard Steunenberg, Coordinating Sectoral Policymaking: Searching for Countervailing Mechanisms in the EU Legislative Process, March 2003

889 Eytan Sheshinski, Optimum Delayed Retirement Credit, March 2003

890 Frederick van der Ploeg, Rolling Back the Public Sector - Differential effects on employment, investment and growth, March 2003

891 Paul De Grauwe and Marc-Alexandre Sénégas, Monetary Policy in EMU when the Transmission is Asymmetric and Uncertain, March 2003 
892 Steffen Huck and Kai A. Konrad, Strategic Trade Policy and the Home Bias in Firm Ownership Structure, March 2003

893 Harry Flam, Turkey and the EU: Politics and Economics of Accession, March 2003

894 Mathias Hoffmann and Ronald MacDonald, A Re-examination of the Link between Real Exchange Rates and Real Interest Rate Differentials, March 2003

895 Badi H. Baltagi, Espen Bratberg, and Tor Helge Holmås, A Panel Data Study of Physicians' Labor Supply: The Case of Norway, March 2003

896 Dennis C. Mueller, Rights and Citizenship in the European Union, March 2003

897 Jeremy Edwards, Gains from Trade in Tax Revenue and the Efficiency Case for Trade Taxes, March 2003

898 Rainer Fehn and Thomas Fuchs, Capital Market Institutions and Venture Capital: Do They Affect Unemployment and Labour Demand?, March 2003

899 Ronald MacDonald and Cezary Wójcik, Catching Up: The Role of Demand, Supply and Regulated Price Effects on the Real Exchange Rates of Four Accession Countries, March 2003

900 R. Selten, M. Schreckenberg, T. Pitz, T. Chmura, and S. Kube, Experiments and Simulations on Day-to-Day Route Choice-Behaviour, April 2003

901 Stergios Skaperdas, Restraining the Genuine Homo Economicus: Why the Economy Cannot be Divorced from its Governance, April 2003

902 Yin-Wong Cheung, Menzie D. Chinn, and Antonio Garcia Pascual, What Do We Know about Recent Exchange Rate Models? In-Sample Fit and Out-of-Sample Performance Evaluated, April 2003

903 Mika Widgrén, Enlargements and the Principles of Designing EU - DecisionMaking Procedures, April 2003

904 Phornchanok Cumperayot, Dusting off the Perception of Risk and Returns in FOREX Markets, April 2003

905 Kai A Konrad, Inverse Campaigning, April 2003

906 Lars P. Feld and Stefan Voigt, Economic Growth and Judicial Independence: Cross Country Evidence Using a New Set of Indicators, April 2003

907 Giuseppe Bertola and Pietro Garibaldi, The Structure and History of Italian Unemployment, April 2003

908 Robert A.J. Dur and Otto H. Swank, Producing and Manipulating Information, April 2003 
909 Christian Gollier, Collective Risk-Taking Decisions with Heterogeneous Beliefs, April 2003

910 Alexander F Wagner, Mathias Dufour, and Friedrich Schneider, Satisfaction not Guaranteed - Institutions and Satisfaction with Democracy in Western Europe, April 2003

911 Ngo Van Long, Raymond Riezman, and Antoine Soubeyran, Trade, Wage Gaps, and Specific Human Capital Accumulation, April 2003

912 Andrea Goldstein, Privatization in Italy 1993-2002: Goals, Institutions, Outcomes, and Outstanding Issues, April 2003

913 Rajshri Jayaraman and Mandar Oak, The Signaling Role of Municipal Currencies in Local Development, April 2003

914 Volker Grossmann, Managerial Job Assignment and Imperfect Competition in Asymmetric Equilibrium, April 2003

915 Christian Gollier and Richard Zeckhauser, Collective Investment Decision Making with Heterogeneous Time Preferences, April 2003

916 Thomas Moutos and William Scarth, Some Macroeconomic Consequences of Basic Income and Employment Subsidies, April 2003

917 Jan C. van Ours, Has the Dutch Miracle Come to an End?, April 2003

918 Bertil Holmlund, The Rise and Fall of Swedish Unemployment, April 2003

919 Bernd Huber and Marco Runkel, Optimal Design of Intergovernmental Grants under Asymmetric Information, April 2003

920 Klaus Wälde, Endogenous Business Cycles and Growth, April 2003

921 Ramon Castillo and Stergios Skaperdas, All in the Family or Public? Law and Appropriative Costs as Determinants of Ownership Structure, April 2003

922 Peter Fredriksson and Bertil Holmlund, Improving Incentives in Unemployment Insurance: A Review of Recent Research, April 2003

923 Bernard M.S. van Praag and Adam S. Booij, Risk Aversion and the Subjective Time Discount Rate: A Joint Approach, April 2003

924 Yin-Wong Cheung, Dissecting the PPP Puzzle: The Unconventional Roles of Nominal Exchange Rate and Price Adjustment, April 2003

925 Ugo Trivellato and Anna Giraldo, Assessing the 'Choosiness' of Job Seekers. An Exploratory Approach and Evidence for Italy, April 2003

926 Rudi Dornbusch and Stanley Fischer, International Financial Crises, April 2003 